\title{
Structural and Catalytic Characterization of a Heterovalent Mn(II)Mn(III) Complex That Mimics Purple Acid Phosphatases
}

\author{
Sarah J. Smith, ${ }^{\dagger}$ Mark J. Riley, ${ }^{,}{ }^{\dagger}$ Christopher J. Noble, ${ }^{\ddagger}$ Graeme R. Hanson, ${ }^{\ddagger}$ Robert Stranger,${ }^{\S}$ Vidura Jayaratne, ${ }^{\S}$ \\ Germán Cavigliasso, ${ }^{\S}$ Gerhard Schenk, ${ }^{\dagger}$ and Lawrence R. Gahan ${ }^{\star}, \dagger$ \\ ${ }^{\dagger}$ School of Chemistry and Molecular Biosciences, ${ }^{*}$ Centre for Magnetic Resonance, The University of \\ Queensland, Brisbane 4072, Australia, and ${ }^{\S}$ Research School of Chemistry, Australian National University, \\ Canberra 0200, Australia
}

Received March 15, 2009

\begin{abstract}
The binuclear heterovalent manganese model complex $\left[\mathrm{Mn}(\mathrm{II}) \mathrm{Mn}(\mathrm{III})(\mathrm{L} 1)(\mathrm{OAc})_{2}\right] \mathrm{ClO}_{4} \cdot \mathrm{H}_{2} \mathrm{O}\left(\mathrm{H}_{2} \mathrm{~L} 1=2-(((3-)((\right.$ bis(pyridin-2-ylmethyl)amino)methyl)-2-hydroxy-5-methylbenzyl)(pyridin-2-ylmethyl)amino)-methyl)phenol) has been prepared and studied structurally, spectroscopically, and computationally. The magnetic and electronic properties of the complex have been related to its structure. The complex is weakly antiferromagnetically coupled $\left(\mathrm{J} \sim-5 \mathrm{~cm}^{-1}\right.$, $\mathbf{H}=-2 J S_{1} \cdot S_{2}$ ) and the electron paramagnetic resonance (EPR) and magnetic circular dichroism (MCD) spectra identify the Jahn-Teller distortion of the $\mathrm{Mn}(\mathrm{III})$ center as predominantly a tetragonal compression, with a significant rhombic component. Electronic structure calculations using density functional theory have confirmed the conclusions derived from the experimental investigations. In contrast to isostructural $\mathrm{M}(\mathrm{II}) \mathrm{Fe}(\mathrm{III})$ complexes ( $\mathrm{M}=\mathrm{Fe}, \mathrm{Mn}, \mathrm{Zn}, \mathrm{Ni})$, the $\mathrm{Mn}(\mathrm{II}) \mathrm{Mn}(\mathrm{III})$ system is bifunctional possessing both catalase and hydrolase activities, and only one catalytically relevant $p K_{a}(=8.2)$ is detected. Mechanistic implications are discussed.
\end{abstract}

\section{Introduction}

Binuclear manganese clusters are found in a variety of metalloenzyme systems ${ }^{1,2}$ including, among others, arginase, ${ }^{3}$ bacteriophage $\lambda$ protein phosphatase, ${ }^{4,5} \mathrm{SoxB},{ }^{6,7}$ and exonuclease. ${ }^{8} \mathrm{~A}$ binuclear manganese derivative of a purple acid phosphatase from sweet potato (SP-PAP) has recently been isolated and characterized by EPR spectroscopy. 2,9

There has been considerable interest in binuclear manganese model systems as potential biomimetics, in particular for

*To whom correspondence should be addressed. E-mail: m.riley@uq.edu. au (M.J.R.), gahan@uq.edu.au (L.R.G.). Phone: ++61 733653932 (M.J.R.), ++61 733653844 (L.R.G.). Fax: ++61 733654299 (M.J.R.), ++61733654299 (L.R.G.)

(1) Dismukes, G. C. Chem. Rev. 1996, 96, 2909.

(2) Smith, S. J.; Hadler, K. S.; Hanson, G. R.; Schenk, G.; Mitić, N. Binuclear Mn-dependent enzymes. In Biological Magnetic Resonance: High Resolution EPR: Applications to Metalloenzymes and Metals in Medicine; Hanson, G. R.; Berliner L. J., Eds.; Springer: New York, 2009; Vol. 29 (in press).

(3) Ash, D. E.; Cox, J. D.; Christianson, D. W. Arginase: A binuclear manganese metalloenzyme. In Metal Ions in Biological Systems: Manganese and its Role in Biological Processes; Sigel, A., Sigel, H., Eds.; Marcel Dekker, Inc.: New York, 2000; Vol. 37, p 407.

(4) Rusnak, F.; Yu, L.; Todorovic, S.; Mertz, P. Biochemistry 1999, 38, 6943.

(5) Reiter, T. A.; Reiter, N. J.; Rusnak, F. Biochemistry 2002, 41, 15404

(6) Bagchi, A.; Ghosh, T. C. Biochem. Biophys. Res. Commun. 2005, 335, 609

(7) Epel, B.; Schaefer, K. O.; Quentmeier, A.; Friedrich, C.; Lubitz, W.

J. Biol. Inorg. Chem. 2005, 10, 636.

(8) Mullen, G. P.; Sepersu, E. H.; Ferrin, L. J.; Loeb, L. A.; Midvan, A. S. J. Biol. Chem. 1990, 265, 14327.

(9) Mitić, N.; Noble, C. J.; Gahan, L. R.; Hanson, G. R.; Schenk, G., J. Am. Chem. Soc. 2009, 131, 8173 . catalase enzymes. ${ }^{10,11}$ A range of binuclear manganese complexes with catalase activity ranging from $k_{\mathrm{cat}}=0.017 \mathrm{~s}^{-1}-$ $250 \mathrm{~s}^{-1}$ have been reported ${ }^{12,13}$ (in comparison enzyme systems operate in the range of $\left.\sim 10^{5} \mathrm{~s}^{-1}\right)^{12,14}$. One such catalase model complex ${ }^{15}$ is the $\mathrm{Mn}(\mathrm{II}) \mathrm{Mn}(\mathrm{III})$ complex with the ligand $\mathbf{L 1}^{\mathbf{2}-}\left(\mathrm{H}_{2} \mathbf{L 1}=2-(((3-)(\right.$ bis(pyridin-2-ylmethyl)amino)methyl)-2-hydroxy-5-methylbenzyl)(pyridin-2-ylmethyl)amino)-methyl)phenol as shown in Scheme 1). The complex shows significant catalase activity, with a $k_{\text {cat }}=2.48 \pm$ $0.15 \mathrm{~s}^{-1}$ and a $K_{\mathrm{M}}=83 \pm 1 \mathrm{mM}$ and has been previously characterized by structural determination and electrochemistry. ${ }^{15}$ Electrochemical measurements have indicated that the heterovalent oxidation state is stabilized by the asymmetry of the ligand, similar to the isostructural $\mathrm{Fe}(\mathrm{II}) \mathrm{Fe}(\mathrm{III})$ complex. ${ }^{16}$ The latter is a biomimetic model for PAPs,

(10) Barynin, V. V.; Whittaker, M. M.; Antonyuk, S. V.; Lamzin, V. S.; Harrison, P. M.; Artymiuk, P. J.; Whittaker, J. W. Structure 2001, 9, 725.

(11) Yoder, D. W.; Hwang, J.; Penner-Hahn, J. E. Manganese catalases. In Metal Ions in Biological Systems; Sigel, A., Sigel, H., Eds.; Marcel Dekker, Inc.: New York, 2000; Vol. 37, p 527.

(12) Wu, A. J.; Penner-Hahn, J. E.; Pecoraro, V. L. Chem. Rev. 2004, 104, 903.

(13) de Boer, J. W.; Browne, W. R.; Feringa, B. L.; Hage, R. C. R. Chim. 2007, 341.

(14) Signorella, S.; Rompel, A.; Buldt-Karentzopoulos, K.; Krebs, B.; Pecoraro, V. L.; Tuchagues, J.-P. Inorg. Chem. 2007, 46, 10864.

(15) Karsten, P.; Neves, A.; Bortoluzzi, A. J.; Strahle, J.; MaichleMossmer, C. Inorg. Chem. Commun. 2002, 5, 434.

(16) Neves, A.; de Brito, M. A.; Drago, V.; Griesar, K.; Haase, W. Inorg. Chim. Acta 1995, 237, 131. 
Scheme 1. $\mathrm{H}_{2} \mathrm{~L} 1$<smiles>Cc1cc(CN(Cc2ccccn2)Cc2ccccn2)c(O)c(CN(Cc2ccccn2)Cc2ccccc2O)c1</smiles>

especially the animal enzymes, which require heterovalent diiron centers for catalytic activity. ${ }^{17,18}$ PAPs catalyze the phophorolysis of a large number of substrates, including predominantly monoesters but also some diesters. ${ }^{18,19}$ The catalytic rates are in the range between $\sim 10 \mathrm{~s}^{-1}$ to $\sim 1,000 \mathrm{~s}^{-1}$ depending on substrate and source of the enzyme (i.e., SP-PAP is faster than animal PAPs). ${ }^{20,21}$ In contrast, the $\mathrm{Fe}(\mathrm{II}) \mathrm{Fe}(\mathrm{III})$ biomimetic is not reactive toward monoester substrates but displays moderate activity toward diester substrates $\left(k_{\text {cat }} \sim 10^{-3} \mathrm{~s}^{-1}\right) .^{16,18,22}$ Because of its structural similarity to PAP biomimetics it was thus timely and of interest to investigate if the above binuclear manganese(III/II) complex with $\mathrm{H}_{2} \mathbf{L} \mathbf{1}$ may be bifunctional, possessing both hydrolytic and catalase activities. In this work a number of spectroscopic and computational techniques were applied to understand the spectral signatures of the binuclear center and to relate these to those of the dimanganese enzyme.

\section{Experimental Section}

2.1. Synthesis of Complex [Mn(II)Mn(III)(L1)(OAc) $\left.)_{2}\right]$ $\mathrm{ClO}_{4} \cdot \mathrm{H}_{2} \mathrm{O}$. The ligand $\mathrm{H}_{2} \mathrm{Ll}$ was prepared as described previously. ${ }^{16}$ A methanolic solution $(20 \mathrm{~mL})$ of $\mathrm{H}_{2} \mathbf{L 1}(134 \mathrm{mg}$, $0.246 \mathrm{mmol})$, manganese acetate tetrahydrate (120 mg, 0.492 $\mathrm{mmol})$, and sodium perchlorate hydrate $(35 \mathrm{mg}, 0.246 \mathrm{mmol})$ was heated to $40{ }^{\circ} \mathrm{C}$ for $30 \mathrm{~min}$, then allowed to stand at room temperature. After slow evaporation of the solvent, the complex formed brown diamond-shaped crystals of diffraction quality (111 mg, 51\%). Elemental analysis: Calcd for $\mathrm{C}_{38} \mathrm{H}_{41} \mathrm{ClMn}_{2^{-}}$ $\mathrm{N}_{5} \mathrm{O}_{11}$ : C, 51.34; H, 4.65; N, 7.88. Found: C, 51.57; H, 4.52; N, $7.73 \%$. UV/vis $\left(\mathrm{CH}_{3} \mathrm{CN}\right): 367 \mathrm{~nm}\left(\varepsilon=3160 \mathrm{M}^{-1} \mathrm{~cm}^{-1}\right), 461 \mathrm{~nm}$ $\left(\varepsilon=2360 \mathrm{M}^{-1} \mathrm{~cm}^{-1}\right)$.

2.2. Computational Methods. Calculations were performed using the Amsterdam Density Functional (ADF 2007)

(17) Bernhardt, P. V.; Schenk, G.; Wilson, G. J. Biochemistry 2004, 43, 10387.

(18) Mitić, N.; Smith, S. J.; Neves, A.; Guddat, L. W.; Gahan, L. R.; Schenk, G. Chem. Rev. 2006, 106, 3338.

(19) Cox, R. S.; Schenk, G.; Mitić, N.; Gahan, L. R.; Hengge, A. C. J. Am. Chem. Soc. 2007, 129, 9550

(20) Schenk, G.; Gahan, L. R.; Carrington, L. E.; Mitić, N.; Valizadeh, M.; Hamilton, S. E.; de Jersey, J.; Guddat, L. W. Proc. Natl. Acad. Sci. U.S.A. 2005, 102, 273.

(21) Schenk, G.; Ge, Y.; Carrington, L. E.; Wynne, C. J.; Searle, I. R.; Carroll, B. J.; Hamilton, S.; de Jersey, J. Arch. Biochem. Biophys. 1999, 370, 183.

(22) Gahan, L. R.; Smith, S. J.; Neves, A.; Schenk, G., Eur. J. Inorg. Chem. 2009, 2745.

(23) Amsterdam Density Functional, Scientific Computing and Modelling; Theoretical Chemistry, Vrije Universiteit: Amsterdam, The Netherlands, 2007.

(24) Fonseca Guerra, C.; Snijders, J. G.; te Velde, G.; Baerends, E. J. Theor. Chem. Acc. 1998, 99, 391.

(25) te Velde, G.; Bickelhaupt, F. M.; van Gisbergen, S. J. A.; Fonseca Guerra, C.; Baerends, E. J.; Snijders, J. G.; Ziegler, T. J. Comput. Chem. 2001, 22, 931 . package. $^{23-25}$ The Vosko-Wilk-Nusair (VWN) form of the local density approximation (LDA) was used, ${ }^{26}$ and GeneralizedGradient-Approximation (GGA) corrections were introduced by using the Becke exchange functional ${ }^{27}$ and the Perdew correlation functional. ${ }^{28}$ Triple $\xi$ basis sets with one polarization function were used for all atoms in the systems. The frozen core approximation for the inner core electrons was employed in the form of $\mathrm{Mn} \cdot 2 \mathrm{p}, \mathrm{O} \cdot 1 \mathrm{~s}, \mathrm{~N} \cdot 1 \mathrm{~s}$, and $\mathrm{C} \cdot 1 \mathrm{~s}$ basis sets, and solvent effects were incorporated with the Conductor-like Screening Model (COSMO) ${ }^{29}$ with water as the solvent. Plots of the molecular orbitals were generated with the MOLEKEL program $^{30,31}$ using data in MOLDEN format ${ }^{32}$ derived from the ADF TAPE21 files.

2.3. EPR Spectroscopy. Continuous wave X-band electron paramagnetic resonance (EPR) spectra were recorded with a Bruker Biospin Elexsys E580 EPR spectrometer fitted with a super high Q cavity. Magnetic field and microwave frequency calibration were achieved with a Bruker ER 036 M Teslameter and a Bruker microwave frequency counter, respectively. Temperatures were controlled using an Oxford flow-through cryostat (ESR910) in conjunction with an Oxford ITC503 temperature controller. Spectrometer tuning, signal averaging, and subsequent spectral comparisons were performed with Bruker's Xepr (version 2.3) software. Computer simulation of the EPR spectrum was performed using the XSophe-SopheXeprView computer simulation software suite (v 1.1.4). ${ }^{33}$

2.4. Magnetic Circular Dichroism. Magnetic circular dichroism (MCD) spectra were obtained from samples in an ethanol/ methanol (50:50) glass in a $1 \mathrm{~mm}$ path length quartz cell, measured at $\pm 7 \mathrm{~T}$ with an Oxford Instruments Spectromag using a Hamamatsu R669 PMT and InGaAs detectors, with a Lastek designed MCD instrument. ${ }^{34}$

2.5. Magnetic Susceptibility. Magnetic susceptibility measurements were made at the School of Chemistry, Monash University, Australia, using a Quantum Design MPMS SQUID magnetometer with an applied field of $1 \mathrm{~T}$ as a function of temperature (ranging from 2 to $300 \mathrm{~K}$ ). The crystalline samples were enclosed in a calibrated gelatin capsule positioned in the center of a drinking straw fixed to the end of the sample rod.

\section{Results}

3.1. X-ray Crystal Structure. The crystal structure of $\left[\mathrm{Mn}(\mathrm{II}) \mathrm{Mn}(\mathrm{III})(\mathbf{L 1})(\mathrm{OAc})_{2}\right] \mathrm{ClO}_{4} \cdot \mathrm{H}_{2} \mathrm{O}$ (see Supporting Information) is very similar to that previously reported for the complex with a tetrafluoroborate counterion. ${ }^{15}$ The Oak Ridge Thermal Ellipsoid Plot (ORTEP) diagram of the $\left[\mathrm{Mn}(\mathrm{II}) \mathrm{Mn}(\mathrm{III})(\mathbf{L 1})(\mathrm{OAc})_{2}\right]^{+}$cation is shown in Figure 1.

3.2. Mass Spectrometry. The mass spectrum of the complex in acetonitrile (Supporting Information, Figure S1) exhibits two major ion peaks which correspond to $\left[\mathrm{Mn}(\mathrm{II}) \mathrm{Mn}(\mathrm{III})(\mathbf{L 1})(\mathrm{OAc})_{2}\right]^{+}(m / z \quad 771)$ and $[\mathrm{Mn}(\mathrm{II})-$ $\mathrm{Mn}(\mathrm{III})(\mathbf{L 1})(\mathrm{OAc})(\mathrm{OMe})]^{+}(\mathrm{m} / z$ 743), the latter likely because of trace amounts of methanol. In methanol (Supporting Information, Figure S1, right), the base peak

(26) Vosko, S. H.; Wilk, L.; Nusair, M. Can. J. Phys. 1980, 58, 1200.

(27) Becke, A. D. Phys. Rev. A 1998, 38, 3098.

(28) Perdew, J. P. Phys Rev B 1986, 33, 8822.

(29) Pye, C. C.; Ziegler, T. Theor. Chem. Acc. 1999, 101, 396

(30) MOLEKEL: An Interactive Molecular Graphics Tool.

(31) Portmann, S.; Lüthi, H. P. Chimia 2000, 54, 766.

(32) Schaftenaar, G.; Noordik, J. H. J. Comput. Aided Mol. Design 2000, $14,123$.

(33) Hanson, G. R.; Gates, K. E.; Noble, C. J.; Griffin, M.; Mitchell, A.; Benson, S. J. Inorg. Biochem. 2004, 98, 903.

(34) Riley, M. J.; Krausz, E. R.; Stanco, A. J. Inorg. Biochem. 2003, 96, 217. 


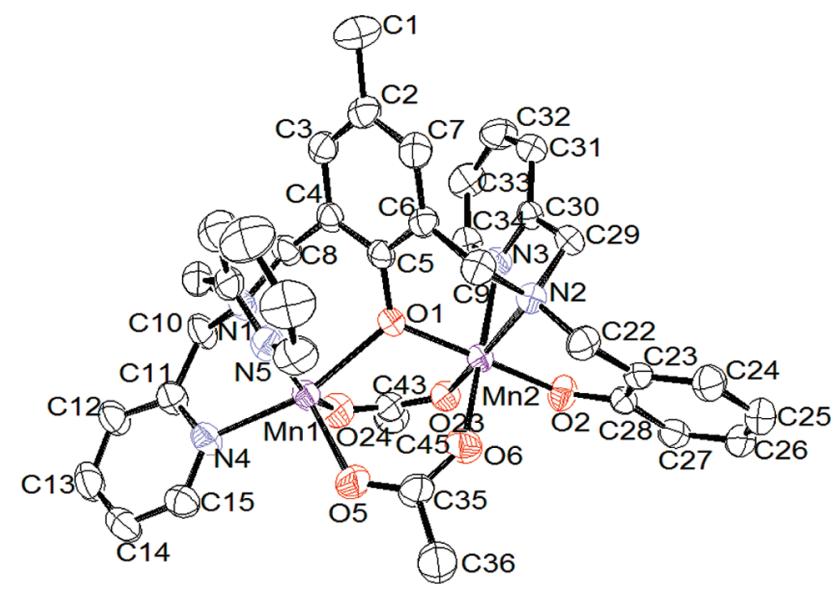

Figure 1. ORTEP plot of $\left[\mathrm{Mn}(\mathrm{II}) \mathrm{Mn}(\mathrm{III})(\mathrm{L1})(\mathrm{OAc})_{2}\right]^{+}$cation. Thermal ellipsoids are shown at $30 \%$ probability, hydrogen atoms are excluded for clarity. The bond lengths are Mn1-O5 = 2.070(4) $\mathrm{A}, \mathrm{Mn} 1-\mathrm{O} 24=$ 2.144(4) $\AA, \mathrm{Mn} 1-\mathrm{O} 1=2.192(3) \AA, \mathrm{Mn} 1-\mathrm{N} 4=2.252(5) \AA, \mathrm{Mn} 1-$ $\mathrm{N} 5=2.288(5) \AA, \mathrm{Mn} 1-\mathrm{N} 1=2.297(4) \AA$ and $\mathrm{Mn} 2-\mathrm{O} 2=1.839(3) \AA$, $\mathrm{Mn} 2-\mathrm{O} 1=1.925(3) \AA, \mathrm{Mn} 2-\mathrm{O} 23=1.985(4) \AA{ }_{3} \mathrm{Mn} 2-\mathrm{N} 2=2.120(4)$ $\AA, \mathrm{Mn} 2-\mathrm{O} 6=2.145(4) \AA, \mathrm{Mn} 2-\mathrm{N} 3=2.271(4) \AA$ where $\mathrm{Mn} 1$ and Mn2 denote the $\mathrm{Mn}(\mathrm{II})$ and $\mathrm{Mn}(\mathrm{III})$ centers, respectively.

is a monoacetate species $\left[\mathrm{Mn}(\mathrm{II})_{2}(\mathbf{L 1})(\mathrm{OAc})\right]^{+}(\mathrm{m} / z$ 712), which requires the reduction of one of the manganese ions. Other peaks apparent in the spectrum include the anticipated $[\mathrm{Mn}(\mathrm{II}) \mathrm{Mn}(\mathrm{III})(\mathrm{L1})(\mathrm{OAc})(\mathrm{OMe})]^{+}$species $\left(m / z\right.$ 743), $\left[\mathrm{Mn}(\mathrm{II})_{2}(\mathbf{L 1})(\mathrm{OMe})\right]^{+}(\mathrm{m} / \mathrm{z} 684)$ and a proposed $\mu$-oxo bridged species $[\mathrm{Mn}(\mathrm{II}) \mathrm{Mn}(\mathrm{III})(\mathrm{L1})(\mathrm{O})]^{+}$ $(m / z$ 669). The expected isotopic patterns (Supporting Information, Figure S1, inset) are observed in all cases. High molecular weight $(\mathrm{m} / \mathrm{z}>900)$ species, likely because of association adducts with solvent or anion species, were also apparent.

With the acetonitrile:water (50:50) solvent used for kinetic assays, the major peak in the spectrum (data not shown) corresponds to the species $\left[\mathrm{Mn}(\mathrm{II})_{2}(\mathbf{L 1})\right.$ $\left.\left(\mathrm{OH}_{2}\right)(\mathrm{OH})\right]^{+}(m / z$ 688 $)$, in which the acetate bridges have been replaced by aqua/hydroxo ligands, and the trivalent manganese has been reduced to manganese(II). Reduction of transition metal ions has previously been observed under the conditions of electrospray ionization. ${ }^{35-38}$ However, the lack of resonances associated with a weakly antiferromagnetically coupled dinuclear Mn(II) center in the EPR and MCD solution studies below indicate the $\mathrm{Mn}$ (II)Mn(III) oxidation states are preserved under normal conditions with methanol/ethanol solvents. We also note that no acetate bridged species are observed in the mass spectrum recorded under the conditions used for kinetic assays.

3.3. Phosphatase-Like Kinetics. Previously, catalase activity toward $\mathrm{H}_{2} \mathrm{O}_{2}$ for $\left[\mathrm{Mn}(\mathrm{II}) \mathrm{Mn}(\mathrm{III})(\mathbf{L 1})(\mathrm{OAc})_{2}\right]^{+}$ was reported. ${ }^{15}$ Here, the hydrolytic activity of the complex was assessed using 2,4-bis(dinitrophenyl)phosphate

(35) Budimir, N.; Fournier, F.; Bailly, T.; Burgada, R.; Tabet, J.-C. Rapid Commun. Mass Spectrom. 2005, 19, 1822.

(36) Gianelli, L.; Amendola, V.; Fabbrizzi, L.; Pallavicini, P.; Mellerio, G. G. Rapid Commun. Mass Spectrom. 2001, 15, 2347.

(37) Ross, A. R. S.; Ikonomou, M. G.; Thompson, J. A. J.; Orians, K. J. Anal. Chem. 1998, 70, 2225.

(38) de Boer, J. W.; Browne, W. R.; Brinksme, J.; Aisters, P. L.; Hage, R.; Feringa, B. L. Inorg. Chem. 2007, 46, 6353. (a)

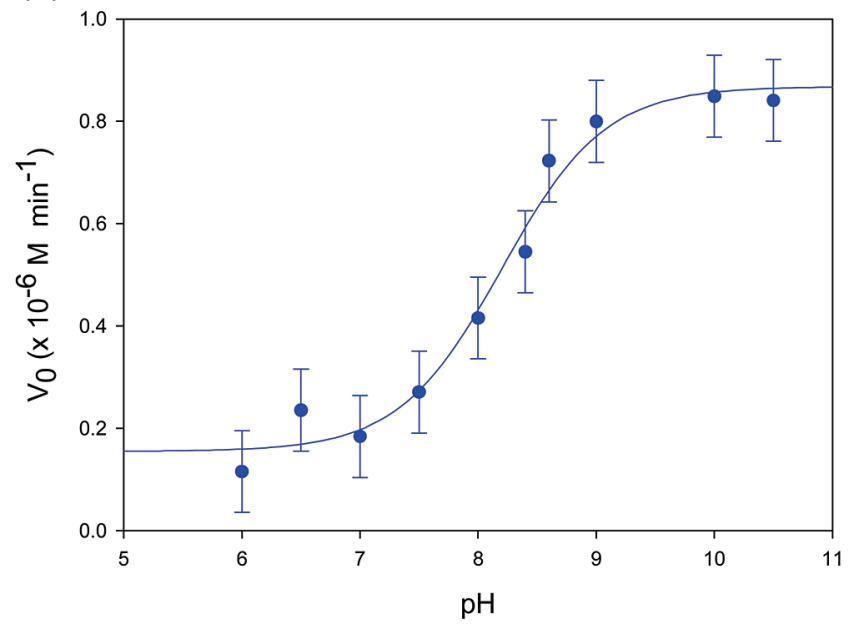

(b)
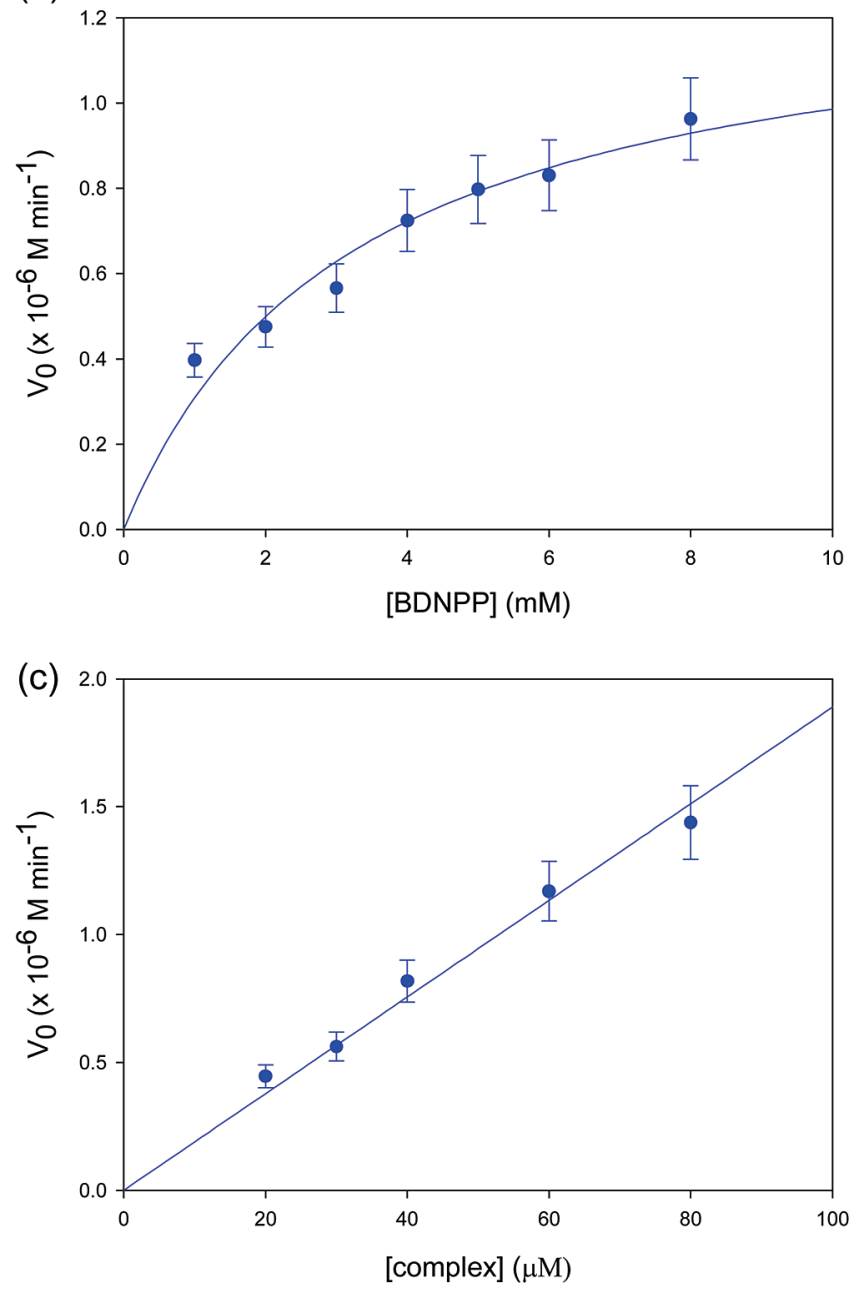

Figure 2. Catalytic properties of $\left[\mathrm{Mn}(\mathrm{II}) \mathrm{Mn}(\mathrm{III})(\mathrm{L1})(\mathrm{OAc})_{2}\right] \mathrm{ClO}_{4} \cdot \mathrm{H}_{2} \mathrm{O}$. (a) $\mathrm{pH}$ dependence (5 mM substrate); (b) substrate dependence at $\mathrm{pH} 10$; (c) complex dependence at $\mathrm{pH} 10$.

(BDNPP) as the substrate (Figure 2). The activity maximizes at $\sim p H \geq 10$, and fitting the data to eq 1 , derived for a monoprotic system, yields a $\mathrm{p} K_{\mathrm{a}}$ of 8.2 .

$$
k_{\text {cat }(\text { observed })}=k_{\mathrm{cat}(\min )}+\frac{k_{\mathrm{cat}(\max )}}{\left(1+\frac{\left[\mathrm{H}^{+}\right]}{K_{\mathrm{es}}}\right)}
$$




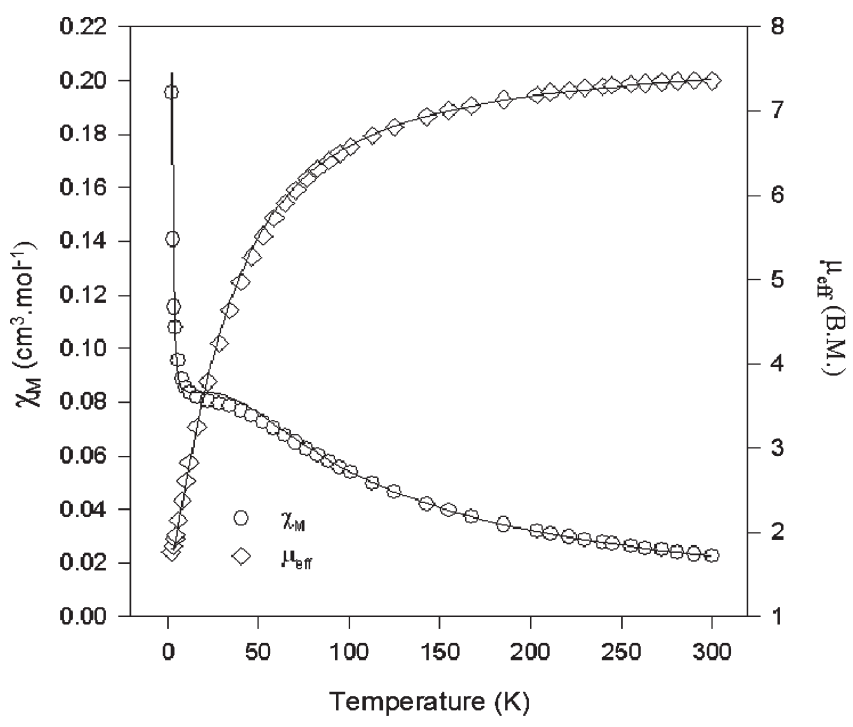

Figure 3. Molar paramagnetic susceptibility per complex, $\chi_{\mathrm{M}}$ (circles), and effective magnetic moment per molecule, $\mu_{\mathrm{eff}}$ (diamonds), versus temperature. The solid lines represent the least-squares fit of the data.

Substrate dependence was measured at pH 10 (Figure 2b), and analyzed using the Michaelis-Menten equation, yielding $k_{\text {cat }}=5.4( \pm 0.6) \times 10^{-4} \mathrm{~s}^{-1}$ and $K_{\mathrm{M}}=3.2 \pm$ $0.8 \mathrm{mM}$. The rate of hydrolysis is linearly dependent on complex concentration (Figure 2c), as is typically seen for model complexes of this type.

3.4. Magnetic Susceptibility. Solid state magnetic susceptibility data were collected for [Mn(II)Mn(III)(L1) $\left.(\mathrm{OAc})_{2}\right] \mathrm{ClO}_{4} \cdot \mathrm{H}_{2} \mathrm{O}$ from 2 to $300 \mathrm{~K}$. The value of $\mu_{\text {eff }}$ at $300 \mathrm{~K}, 7.37 \mu_{\mathrm{B}}$, is consistent with high spin $\mathrm{Mn}(\mathrm{II})$ and $\mathrm{Mn}(\mathrm{III})$ ions that are weakly exchange coupled. The data points shown as symbols in Figure 3 were fitted to the simple Van Vleck equation ${ }^{39}$ derived for $S_{1}=$ $5 / 2, S_{2}=2$.

$$
\chi_{\mathrm{M}}=\frac{N g^{2} \beta^{2}}{4 k(T-\theta)} \cdot \frac{\left(165 \mathrm{e}^{24 x}+84 \mathrm{e}^{15 x}+35 \mathrm{e}^{8 x}+10 \mathrm{e}^{3 x}+1\right)}{\left(5 \mathrm{e}^{24 x}+4 \mathrm{e}^{15 x}+3 \mathrm{e}^{8 x}+2 \mathrm{e}^{3 x}+1\right)}
$$

In the above equation, $x=J / k T$ (for $H=-2 J S_{1} \cdot S_{2}$ ), $g$ is the average $g$-value and $\theta$ is the Curie-Weiss constant. Least squares fitting of $\chi_{M}$ to the above expression results in the solid line in Figure 3 with the parameters $J=-4.18$ $\mathrm{cm}^{-1}, g=2.02$ and $\theta=0.11$. The inclusion of tetragonal zero field splitting parameters resulted in a similar value of $J=-5.0 \mathrm{~cm}^{-1}$, with $\left|D_{1}\right|<0.1 \mathrm{~cm}^{-1}$ and $\left|D_{2}\right|$ of the order $\sim 5 \mathrm{~cm}^{-1}$. Importantly, when the full Hamiltonian is used the Curie-Weiss constant, which often implies a ferromagnetic interaction, is not required. However, we note that the fit is relatively insensitive to the values of $D$ and that the $\operatorname{Mn}$ (III) $S=2$ site will have a large rhombic component, and for this reason we cannot quantify the zero-field splitting parameters with certainty.

3.5. EPR Spectroscopy. The frozen solution (methanol) EPR spectrum (Figure 4) shows highly resolved features around $g \sim 2$ at $1.5 \mathrm{~K}$, indicative of an $S=1 / 2$ ground state as would be expected for an antiferromagnetically coupled $\mathrm{Mn}(\mathrm{II}) \mathrm{Mn}(\mathrm{III})$ system. To simplify

(39) O'Connor, C. J. Prog. Inorg. Chem. 1982, 29, 203. calculations, only the ground state of the complex was simulated using eq 3 and the XSophe-Sophe-XeprView computer simulation software suite ${ }^{33}$ with an effective $S=1 / 2$ spin Hamiltonian.

$$
\begin{aligned}
\mathrm{H}=\beta \underline{\mathrm{B}} \cdot \mathrm{g} \cdot \underline{\mathrm{S}}+\underline{\mathrm{S}} \cdot \mathrm{A}_{1} \cdot \underline{\mathrm{I}}_{1}+\underline{\mathrm{S}} \cdot \mathrm{A}_{2} \cdot \underline{\mathrm{I}}_{2} \\
-\mathrm{g}_{\mathrm{n}} \beta_{\mathrm{n}} \underline{\mathrm{B}} \cdot \underline{\mathrm{I}}_{1}-\mathrm{g}_{\mathrm{n}} \beta_{\mathrm{n}} \underline{\mathrm{B}} \cdot \underline{\mathrm{I}}_{2}
\end{aligned}
$$

Here, the subscripts 1 and 2 refer to the $\mathrm{Mn}(\mathrm{II})$ and $\mathrm{Mn}$ (III) ions. Rhombic g- and A-matrices were necessary for the simulation illustrated in Figure 4, using the parameters given in Table 1. In addition to the intrinsic line widths $\left(\sigma \mathrm{R}_{x, y, z}=49.10,112.71,33.29 \times 10^{-4} \mathrm{~cm}^{-1}\right)$, broadening was simulated using g- and A-strain, $\left(\sigma \mathrm{g}_{x, y, z}\right)$ $\mathrm{g}_{x, y, z}=-0.0244,0.0281,-0.0010 ; \sigma \mathrm{A}_{x, y, z}=8.471,-8.517$, $\left.-10.241 \times 10^{-4} \mathrm{~cm}^{-1}\right)$. The simulation parameters are typical for complexes of this type, and Table 1 contains some values for comparison.

The temperature dependence of the EPR spectrum is shown in Figure $4 \mathrm{~b}$. As the temperature is raised a low field transition $\left(g_{\text {eff }} \sim 6\right)$ emerges, reaching a maximum around $10 \mathrm{~K}$ before it gradually disappears, concomitant with a shift of the resonance to a lower magnetic field. Deconvolution studies revealed that it is composed of two components at $g_{\text {eff }} \sim 5.6$ and 7.0. The $g_{\text {eff }} \sim 5.6$ resonance initially increases in intensity with temperature up to about $4 \mathrm{~K}$ and then decreases, while the $g_{\text {eff }} \sim 7.0$ resonance increases with increasing temperature. While the $g_{\text {eff }} \sim 5.6$ resonance arises from a transition within the $\pm|3 / 2\rangle$ doublet of an $S=3 / 2$ spin state, the $g_{\text {eff }} \sim 7.0$ resonance most likely arises from a transition within a $\pm|1 / 2\rangle$ doublet of an $S=5 / 2$ excited spin state where the zero field splitting parameter $(D)$ is greater than the microwave quantum. ${ }^{40-43}$ Quantitative analysis of the variable temperature data for $g_{\text {eff }} \sim 5.6$ resonance proved impossible as a result of spin-lattice relaxation. ${ }^{43,44}$ Because of the weak exchange coupling, the excited $S=$ $3 / 2$ and $5 / 2$ transitions would be expected to appear at relatively low temperatures. ${ }^{42}$ For example, on the basis of a $J$ of $-5 \mathrm{~cm}^{-1}$, the $S=3 / 2$ state would be $\sim 24 \%$ populated at $10 \mathrm{~K}$. The $S=1 / 2$ resonances decrease in intensity as the temperature increases, and at high temperatures, the only remaining features apparent around $g=2$ correspond to a minor monomeric high spin $\mathrm{Mn}$ (II) impurity as is apparent from the magnetic susceptibility data (Figure 3). Attempts to fit the intensity of the resonances to the appropriate Boltzmann populations were unsuccessful as the intensity of both resonances decay more rapidly than would be expected. This is typical of weakly exchange coupled $\mathrm{Mn}$ (II)Mn(III) systems where rapid Orbach relaxation leads to loss of the

(40) Dubois, L.; Xiang, D.-F.; Tan, X.-S.; Pecaut, J.; Jones, P.; Baudron, S.; Le Pape, L.; Latour, J.-M.; Baffert, C.; Chardon-Noblat, S.; Collomb, M.-N.; Deronzier, A. Inorg. Chem. 2003, 42, 750.

(41) Diril, H.; Chang, H.-R.; Nilges, M. J.; Zhang, X.; Potenza, J. A.; Schugar, H. J.; Isied, S. S.; Hendrickson, D. N. J. Am. Chem. Soc. 1989, 111, 5102 .

(42) Anderlund, M. F.; Hogblom, J.; Shi, W.; Huang, P.; Eriksson, L.; Weihe, H.; Styring, S.; Akermark, B.; Lomoth, R.; Magnuson, A. Eur. J. Inorg. Chem. 2006, 5033.

(43) Abragam, A.; Bleaney, B. Electron paramagnetic resonance of transition ions; Clarendon Press: Oxford, 1970.

(44) Teutloff, C.; Schafer, K.-O.; Sinnecker, S.; Barynin, V. V.; Bittl, R.; Wieghardt, K.; Lendzian, F.; Lubitz, W. Magn. Reson. Chem. 2005, 43, S51. 
a)

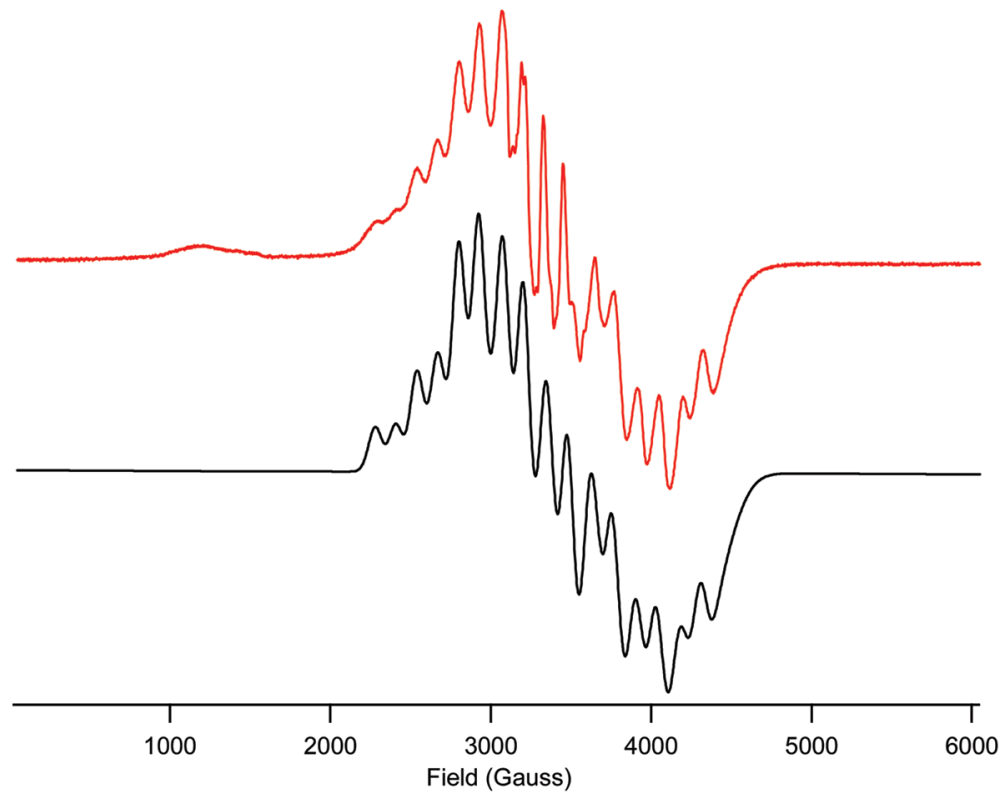

b)

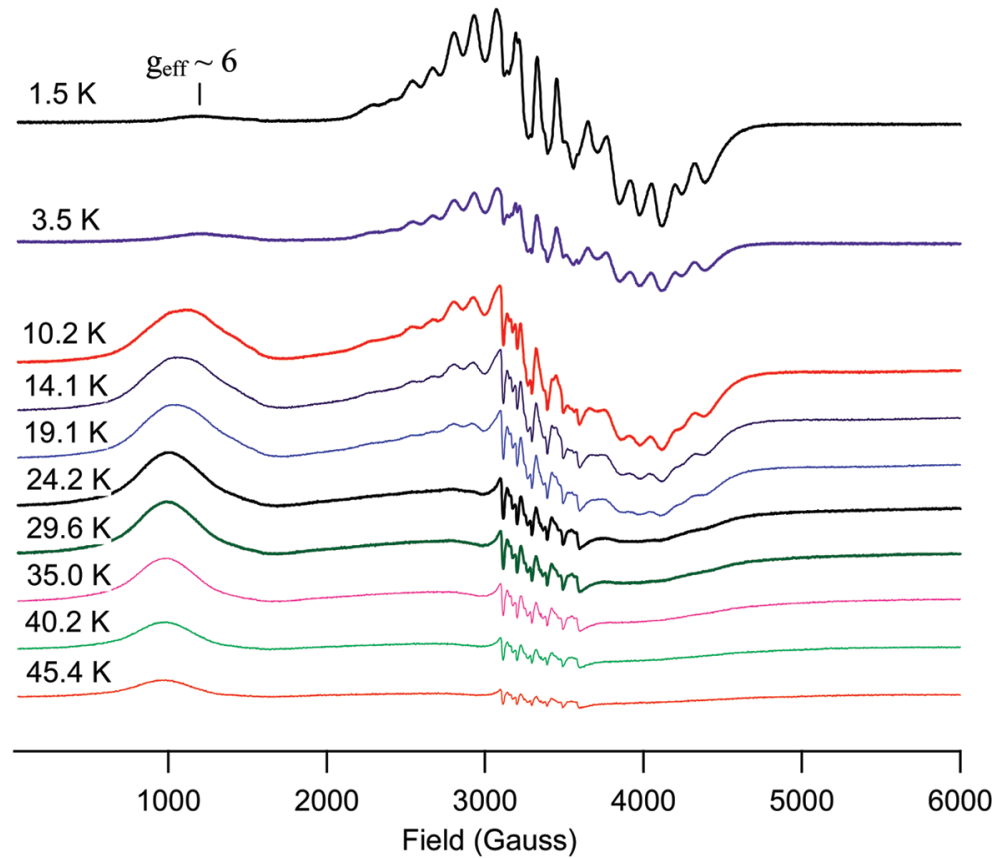

Figure 4. (a) Experimental (above) and simulated (below) X-band EPR spectra of $\left[\mathrm{Mn}(\mathrm{II}) \mathrm{Mn}(\mathrm{III})(\mathbf{L 1})(\mathrm{OAc})_{2}\right]\left(\mathrm{ClO}_{4}\right)(1 \mathrm{mM}$ in methanol). The spectrum was measured at $1.5 \mathrm{~K}, 0.2 \mathrm{~mW}$ power and $2.00 \mathrm{G}$ modulation amplitude, $v=9.377502 \mathrm{GHz}$. (b) Variable temperature X-band EPR spectra of $\left[\mathrm{Mn}(\mathrm{II}) \mathrm{Mn}(\mathrm{III})(\mathrm{L1})(\mathrm{OAc})_{2}\right] \mathrm{ClO}_{4}$ in a methanol glass. Temperature $=10-55 \mathrm{~K}: 2 \mathrm{~mW}$ power, $4 \mathrm{G}$ modulation amplitude; $T=1.5-3.5 \mathrm{~K}: 0.2 \mathrm{~mW}$ power, $2 \mathrm{G}$ modulation amplitude.

signal at low temperatures. ${ }^{43,44}$ Although mass spectrometry indicated the presence of some reduced species in methanolic solution, the EPR data are consistent with the retention of the heterovalent oxidation states (Mn(II)$\mathrm{Mn}(\mathrm{III}))$ under these conditions.

3.6. MCD and Optical Spectroscopy. The variable temperature $\mathrm{MCD}$ and low temperature absorption spectra of $\left[\mathrm{Mn}(\mathrm{II}) \mathrm{Mn}(\mathrm{III})(\mathbf{L 1})(\mathrm{OAc})_{2}\right]_{\mathrm{ClO}_{4}}$ in an ethanol/ methanol glass are shown in Figures $5 \mathrm{a}$ and $5 \mathrm{~b}$, respectively. The MCD spectra (Figure 5a) show broad negative $(\sim 460 \mathrm{~nm})$ and (less well resolved) positive $(\sim 370 \mathrm{~nm})$ bands which are typical of trivalent manganese

(45) Whittaker, M. M.; Barynin, V. V.; Antonyuk, S. V.; Whittaker, J. W. Biochemistry 1999, 38, 9126. centers, ${ }^{45-47}$ and correspond to the phenolate to $\mathrm{Mn}$ (III) charge transfer transitions which are also evident in the absorption spectrum (Figure $5 \mathrm{~b}$ ). The broad bands show characteristic $C$-term behavior, with the signal intensity rapidly decreasing with increasing temperature. Unusual features of the spectra are the sharp, temperature dependent peaks at 426 and $472 \mathrm{~nm}$. The $426 \mathrm{~nm}$ feature is also clearly resolved in the low temperature absorption spectra (Figure $5 \mathrm{~b}$ ). The relative intensity of these sharp

(46) Brunold, T. C.; Gamelin, D. R.; Stemmler, T. L.; Mandal, S. K.; Armstrong, W. H.; Penner-Hahn, J. E.; Solomon, E. I. J. Am. Chem. Soc. $1998,120,8724$.

(47) Whittaker, J. W.; Whittaker, M. M. J. Am. Chem. Soc. 1991, 113, 5528 
Table 1. EPR Simulation and Line Width Parameters for $\left[\mathrm{Mn}(\mathrm{II}) \mathrm{Mn}(\mathrm{III})(\mathrm{L1})(\mathrm{OAc})_{2}\right] \mathrm{ClO}_{4}$ and Related Complexes Using an Effective $S=1 / 2 \mathrm{Spin}$ Hamiltonian

\begin{tabular}{|c|c|c|c|c|}
\hline & \multirow[b]{2}{*}{$\mathrm{g}_{x}, \mathrm{~g}_{y}, \mathrm{~g}_{z}$} & \multirow{2}{*}{$\frac{\mathrm{Mn}(\mathrm{III})}{\mathrm{A}_{\mathrm{x}}, \mathrm{A}_{y}, \mathrm{~A}_{z}^{a}}$} & \multicolumn{2}{|l|}{$\mathrm{Mn}(\mathrm{II})$} \\
\hline & & & $\mathrm{A}_{x}, \mathrm{~A}_{y}, \mathrm{~A}_{z}^{a}$ & $\mathrm{~W}_{x}, \mathrm{~W}_{y}, \mathrm{~W}_{z}^{a}$ \\
\hline$\left[\mathrm{Mn}(\mathrm{II}) \mathrm{Mn}(\mathrm{III})(\mathbf{L 1})(\mathrm{OAc})_{2}\right]\left(\mathrm{ClO}_{4}\right)^{b}$ & $1.753,1.938,2.015$ & $61,63,123$ & $-157,-120,-262$ & $49,113,33$ \\
\hline$\left[\mathrm{Mn}(\mathrm{II}) \mathrm{Mn}(\mathrm{III})(\mathrm{BPTBMP})(\mathrm{OAc})_{2}\right]\left(\mathrm{ClO}_{4}\right)^{55}$ & $1.844,1.932,2.005$ & $60,66,122$ & $-157,-146,-259$ & $69,86,25$ \\
\hline$\left[\mathrm{Mn}(\mathrm{II}) \mathrm{Mn}(\mathrm{III})(\mathrm{BCMP})(\mathrm{OAc})_{2}\right]\left(\mathrm{ClO}_{4}\right)_{2}{ }^{66}$ & $1.905,1.905,2.022$ & $73,73,106$ & $-153,-153,-245$ & \\
\hline$\left[\mathrm{Mn}(\mathrm{II}) \mathrm{Mn}(\mathrm{III})(\mathrm{BPMP})(\mathrm{OAc})_{2}\right]\left(\mathrm{ClO}_{4}\right)^{41}$ & $1.813,1.883,2.026$ & $65,65,113$ & $-145,-145,-267$ & $67,67,34$ \\
\hline $\mathrm{Mn}(\mathrm{II}) \mathrm{Mn}(\mathrm{III})$ Photosystem II $(+\mathrm{NO})^{118}$ & $1.970,1.970,2.011$ & $76,76,69$ & $-184,-184,-255$ & \\
\hline $\mathrm{Mn}(\mathrm{II}) \mathrm{Mn}(\mathrm{III})$ catalase $^{44}$ & $1.935,1.995,2.016$ & $72,73,72$ & $-174,-171,-241$ & \\
\hline
\end{tabular}

${ }^{a}$ Hyperfine and line-width parameter in units of $\left(\times 10^{-4} \mathrm{~cm}^{-1}\right) .{ }^{b}$ This work.
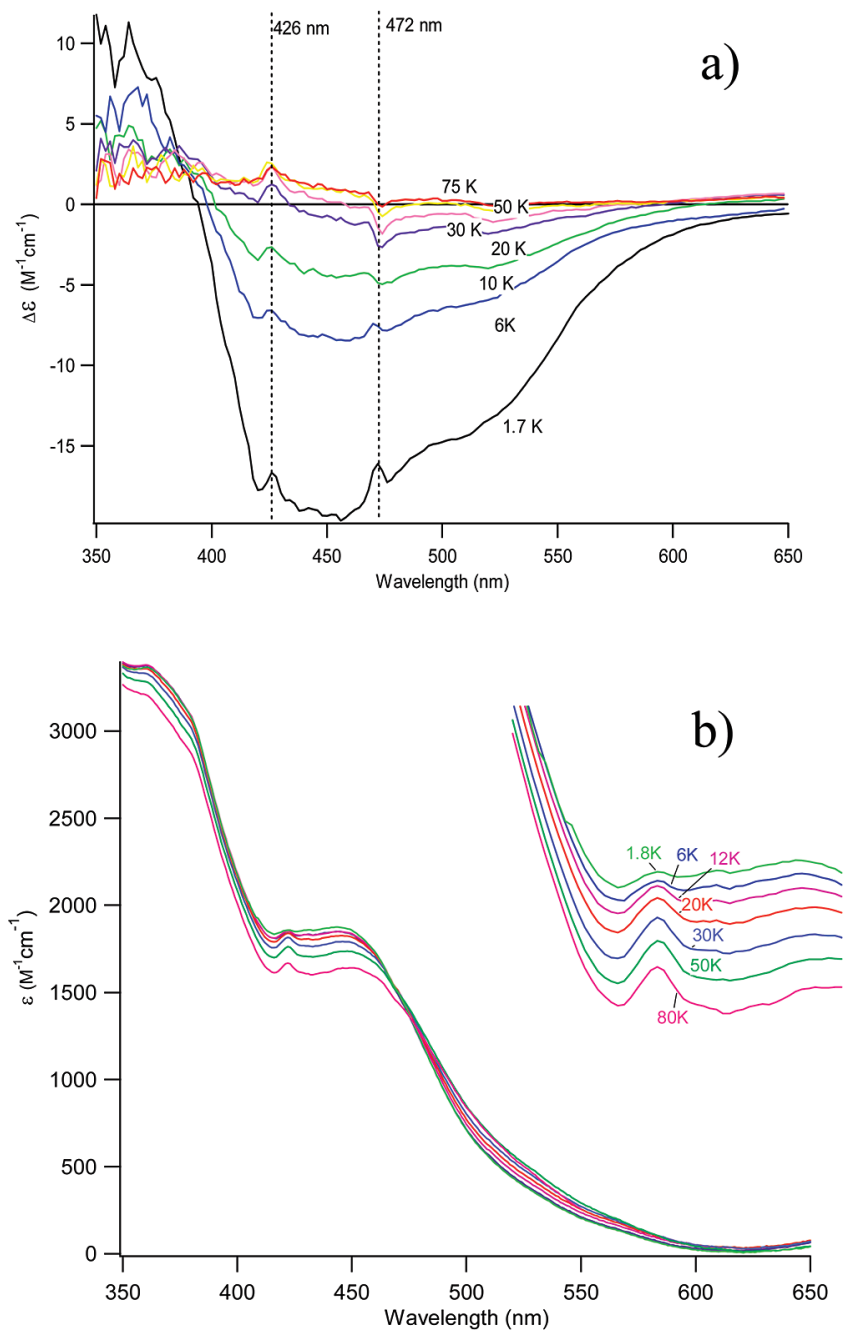

Figure 5. (a) Variable temperature $\mathrm{MCD}$ spectra of [Mn(II)$\left.\mathrm{Mn}(\mathrm{III})(\mathbf{L 1})(\mathrm{OAc})_{2}\right] \mathrm{ClO}_{4}$ measured at $5 \mathrm{~T}$ in a methanol/ethanol glass. (b) Variable temperature absorption spectra of [Mn(II)Mn(III)(L1) $\left.(\mathrm{OAc})_{2}\right] \mathrm{ClO}_{4}$ in a methanol/ethanol glass. Inset shows the $400-$ $450 \mathrm{~nm}$ region, with the temperatures as shown.

features increases with increasing temperature over this temperature range, and interestingly, the MCD of the sharp MCD feature at $472 \mathrm{~nm}$ appears to change sign.

The variable temperature-variable field (VTVH) MCD data measured at $450 \mathrm{~nm}$ are shown in Figure 6, where the nested curves are a consequence of the low energy states of this spin-coupled system. To simulate the data, a coupled $S_{1}=5 / 2, S_{2}=2$ spin Hamiltonian in eq 4 was used, with the coupled basis of dimension $\left(2 S_{1}+1\right) \times$ $\left(2 S_{2}+1\right)$ and the approximations $g\left(S_{1}\right) \sim 2, g\left(S_{2}\right) \sim 2$,

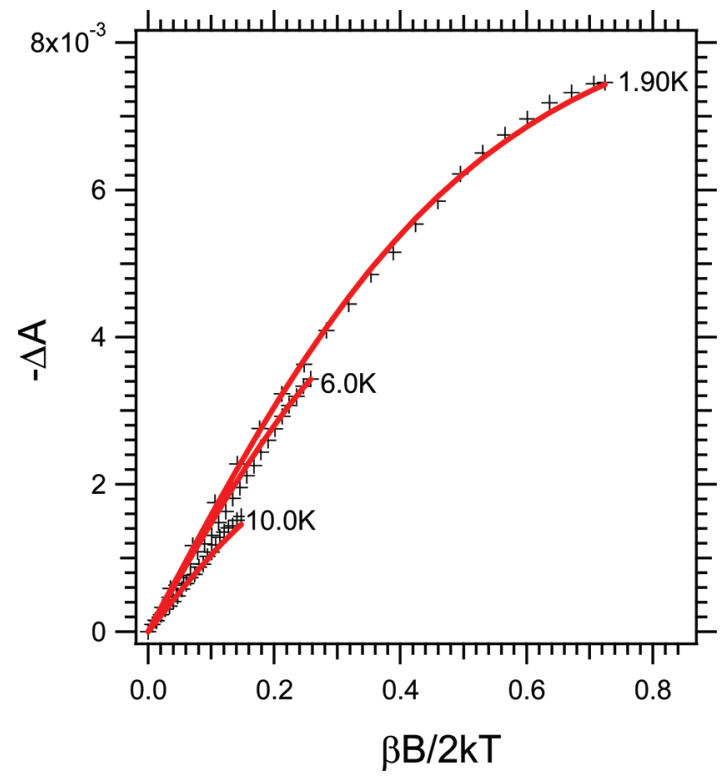

Figure 6. VTVH MCD data of $\left[\mathrm{Mn}(\mathrm{II}) \mathrm{Mn}(\mathrm{III})(\mathrm{L1})(\mathrm{OAc})_{2}\right] \mathrm{ClO}_{4}$ in a methanol/ethanol glass. Solid lines indicate the fit to the data using $J=$ $-4.7 \mathrm{~cm}^{-1}, D(\mathrm{Mn}(\mathrm{III}))=4.3 \mathrm{~cm}^{-1}$.

$D_{2} \sim 0$. Further it was assumed that the metal centers have approximate tetragonal symmetry, with the rhombic zero field splitting parameters zero.

$$
\begin{gathered}
\mathrm{H}=-2 J \underline{\mathrm{S}}_{1} \cdot \underline{\mathrm{S}}_{2}+\mathrm{H}_{\mathrm{s}}\left(\underline{\mathrm{S}}_{1}\right)+\mathrm{H}_{\mathrm{s}}\left(\underline{\mathrm{S}}_{2}\right) \\
\mathrm{H}_{\mathrm{s}}(\mathrm{S})=\beta \underline{\mathrm{B}} \cdot g \cdot \underline{\mathrm{S}}+D\left(S_{z}^{2}-\frac{1}{3} S(S+1)\right)
\end{gathered}
$$

Following the formalism of Neese and Solomon, ${ }^{48}$ the MCD VTVH curves are calculated from

$$
\begin{gathered}
\frac{\Delta \varepsilon}{E}=\frac{-1}{4 \pi S} \int_{0}^{\pi} \int_{0}^{2 \pi} \sum_{i} N_{i}\left(l\left\langle S_{x 1 i}\right\rangle M_{y z 1}+m\left\langle S_{y 1 i}\right\rangle M_{x z 1}+\right. \\
n\left\langle S_{z 1 i}\right\rangle M_{x y 1}+l\left\langle S_{x 2 i}\right\rangle M_{y z 2}+m\left\langle S_{y 2 i}\right\rangle M_{x z 2}+ \\
\left.n\left\langle S_{z 2 i}\right\rangle M_{x y 2}\right) \sin \theta \mathrm{d} \theta \mathrm{d} \phi
\end{gathered}
$$

where the $N_{\mathrm{i}}$ are the Boltzmann populations of the energy levels; $\left\langle S_{x l_{i}}\right\rangle$ is the expectation value of the spin operator $S_{x 1}$ for spin 1 in level $i$ using the eigenvectors from the solutions of (4); and $l, m, n$ specify the direction of the magnetic field with respect to the molecular fixed axis

(48) Neese, F.; Solomon, E. I. Inorg. Chem. 1999, 38, 1847. 
system. The signed $M_{j k i}$ parameters are effective transition moments products $m_{j} m_{k}{ }^{48}$ For a particular field value, eq 5 was numerically integrated by repeated diagonalization of the $30 \times 30$ matrix over Gaussian quadrature grid points in $\theta$ and $\phi$. The principal axes on each center can be related to a common dimer axes system; however, as it is assumed that the phenolate-to-Mn(III) LMCT transition dominates the MCD intensity $\left(M_{\mathrm{xy} 1}=\right.$ $M_{\mathrm{xz} 1}=M_{\mathrm{yz} 1}=0$ ), we define the axes system to be the principal directions of the $\operatorname{Mn}(\mathrm{III})\left(S_{2}=2\right)$ center. The $z$ axis is defined in the $\mathrm{Mn} 2-\mathrm{O} 2$ direction, the $x$ axis perpendicular to the $\mathrm{Mn} 1-\mathrm{O} 1-\mathrm{Mn} 2$ plane.

As discussed below, the exchange coupling is quite sensitive to the $\mathrm{Mn}(\mathrm{III} / \mathrm{II})-\mathrm{O}$ bond lengths, and since there are likely structural changes in solution (such as possible replacement of acetate bridges with methoxy ligands, as suggested by the mass spectrometry), as well as increased flexibility, the $J$ value determined from magnetism was used only as a starting value and allowed to float. The antiferromagnetic nature of the coupling was fixed based on the $S=1 / 2$ ground state observed in the EPR spectra measured in methanol. The parameters $J=$ $-4.7 \pm 0.2 \mathrm{~cm}^{-1}$ and $D(\mathrm{Mn}(\mathrm{III}))=4.3 \pm 0.2 \mathrm{~cm}^{-1}$ were obtained from the fit to the data shown in Figure 6. A small ZFS associated with the divalent manganese was required to fit the data, along with a larger value associated with the trivalent manganese. As with the magnetic susceptibility data, the fit of the VTVH curves was relatively insensitive to the values of the ZFS parameters, as has been seen in other manganese systems, ${ }^{49}$ and the use of the additional rhombic ZFS parameters could not be supported by the data although it can be assumed that the $E$ values are not zero. We also found that for these parameters together with the approximations and coordinate system defined above, the calculated VTVH curves result in the expected $M_{x z 2} \sim M_{y z 2}>M_{x y 2}$, but that the fit is insensitive to the actual value of $M_{x y 2}$.

3.7. Electronic Structure Calculations. The geometry optimized structure of the $\left[\mathrm{Mn}(\mathrm{II}) \mathrm{Mn}(\mathrm{III})(\mathbf{L 1})(\mathrm{OAc})_{2}\right]^{+}$ cation is given in Supporting Information, Table S3, together with a comparison to the experimental data. The average absolute deviation between calculation and experiment is $2-3 \mathrm{pm}$, and the agreement is somewhat better for the $\mathrm{Mn}(\mathrm{II})$ than the $\mathrm{Mn}(\mathrm{III})$ sites. The calculated $\mathrm{Mn}-\mathrm{Mn}$ distance and $\mathrm{Mn}-\mathrm{O}-\mathrm{Mn}$ angle are $3.50 \AA$ and $\sim 116^{\circ}$ respectively, very close to the experimental values $\left(3.49 \AA\right.$ and $\left.115.8^{\circ}\right)$.

It is interesting to compare these values to those calculated for the reduced system [Mn(II)Mn(II)(L1) $\left.(\mathrm{OAc})_{2}\right]$. In this case all metal-ligand distances of the Mn2 site exhibit a significant lengthening which correlates with the change in formal oxidation state from $\mathrm{Mn}(\mathrm{III})$ to $\mathrm{Mn}(\mathrm{II})$. In contrast, the Mn1 site, which does not undergo a change in formal oxidation state, shows only a relatively small increase of the metal-ligand distances, with the exception of the Mn1-O1 distance, which decreases considerably, in opposition to the large increase in the bond length between this bridging oxo site and the Mn2 site. The calculated Mn-Mn distance and $\mathrm{Mn}-\mathrm{O}-\mathrm{Mn}$ angle for the reduced dimer are $3.45 \AA$ and

(49) Jackson, T. A.; Karapetian, A.; Miller, A.-F.; Brunold, T. C. Biochemistry 2005, 44, 1504. $\sim 110^{\circ}$, respectively. A comparison of selected bond lengths of the $\mathrm{Mn}(\mathrm{II}) \mathrm{Mn}(\mathrm{III})$ and $\mathrm{Mn}(\mathrm{II}) \mathrm{Mn}(\mathrm{II})$ dimer systems is given in Supporting Information, Table S4. A Mulliken population analysis (Supporting Information, Table S5) shows values for the atomic charge and spin density consistent with high-spin configurations, with $S=5 / 2$ and $S=2$, respectively, for $\mathrm{Mn}(\mathrm{II})$ and $\mathrm{Mn}(\mathrm{III})$ sites.

\section{Discussion}

4.1. Geometric and Electronic Structural Description of the Mn(II)Mn(III) Complex. 4.1.1. Mn(II)Mn(III) Local Geometry. Both metal centers are six coordinate, with $\mathrm{Mn} 1$ in the softer $\mathrm{N}_{3} \mathrm{O}_{3}$ site and $\mathrm{Mn} 2$ in the harder $\mathrm{N}_{2} \mathrm{O}_{4}$ site. The angle between the metal centers and the bridging phenoxo (Mn1-O1-Mn2) is $115.8^{\circ}$, and the metal-metal distance is $3.492 \AA$ A. A Jahn-Teller distortion is expected for the $\mathrm{Mn}(\mathrm{III})\left(\mathrm{d}^{4}\right)$ center, but the orientation is somewhat ambiguous. Karsten et al. ${ }^{15}$ proposed a tetragonal elongation along the $\mathrm{O} 6-\mathrm{Mn} 2-\mathrm{N} 3$ axis (average bond lengths $2.21 \AA$, compared to the averages 1.88 and $2.05 \AA$ along the other axes). It is also possible to define a tetragonal compression along the $\mathrm{O} 1-\mathrm{Mn} 2-\mathrm{O} 2$ axis $(1.88 \AA)$, but in either case there is a large rhombic component to the ligand field.

The divalent $(\mathrm{Mn} 1)$ and trivalent $(\mathrm{Mn} 2)$ centers are readily distinguished on the basis of bond lengths. ${ }^{50-52} \mathrm{~A}$ Bond Valence Sum (BVS) analysis distinguishes the oxidation states of manganese, and searches of the Cambridge Crystallographic Data Centre (CCDC) have indicated that high spin $\mathrm{Mn}(\mathrm{II}), \mathrm{Mn}(\mathrm{III})$, and $\mathrm{Mn}(\mathrm{IV})$ complexes have BVS values of approximately 1.9, 3.1, and 4.1, respectively. ${ }^{53}$ Applying this methodology to the two metal centers in $\left[\mathrm{Mn}(\mathrm{II}) \mathrm{Mn}(\mathrm{III})(\mathbf{L 1})(\mathrm{OAc})_{2}\right]^{+}$yields a BVS value of 1.98 for Mn1 and 2.99 for Mn2, consistent with the proposed di- and trivalent oxidation states, respectively.

4.1.2. Magnetochemistry and EPR. Fitting of the magnetic susceptibility data indicates that the metal centers are weakly antiferromagnetically coupled. The weak antiferromagnetic coupling is typical of $\mu$-(phenoxo)-bis-( $\mu$-carboxylato) systems and exchange coupling constants of this magnitude have been reported for similar Mn(II)Mn(III) complexes. ${ }^{40-42,54}$ In this complex, use of the simple Van Vleck model (eq 2) is not strictly valid as the $\mathrm{Mn}(\mathrm{III})$ ion is expected to have a $D$ value of the order of the coupling constant $J$. We have fitted the data using the full spin Hamiltonian of the coupled system but because of over parameterization we have had to set the rhombic ZFS parameter $E$ to zero. The treatment of the susceptibility data with and without inclusion of ZFS parameters resulted in very similar values for the coupling constant.

(50) Bortoluzzi, A. J.; Neves, A.; Couto, R. A. A.; Peralta, R. A. Acta Crystallogr. 2006, C62, 27.

(51) Gultneh, Y.; Tesema, Y. T.; Yisgedu, T. B.; Butcher, R. J.; Wang, G.; Yee, G. T. Inorg. Chem. 2006, 45, 3023.

(52) Mikuriya, M.; Fujii, T.; Tokii, T.; Kawamori, A. Bull. Chem. Soc. Jpn. 1993, 66, 1675.

(53) Larsen, F. B.; Boisen, A.; Berry, K. J.; Moubaraki, B.; Murray, K. S.; McKee, V.; Scarrow, R. C.; McKenzie, C. J. Eur. J. Inorg. Chem. 2006, 3841.

(54) Chang, H.-R.; Larsen, S. K.; Boyd, P. D. W.; Pierpont, C. G.; Hendrickson, D. N. J. Am. Chem. Soc. 1988, 110, 4565. 
Table 2. Exchange Coupling Constants and Key Structural Parameters of $\mathrm{Mn}(\mathrm{II}) \mathrm{Mn}(\mathrm{III}) \mu$-Phenoxo-bis( $\mu$-carboxylato) Dimers

\begin{tabular}{llllc}
\hline \multicolumn{1}{c}{ complex } & $J\left(\mathrm{~cm}^{-1}\right)$ & $\mathrm{Mn}(\mathrm{III})-\mathrm{O}(\AA)$ & $\mathrm{Mn}(\mathrm{II})-\mathrm{O}(\AA)$ & $\delta_{\mathrm{Mn}-\mathrm{O}}{ }^{a}(\AA)$ \\
\hline$\left[\mathrm{Mn}(\mathrm{II}) \mathrm{Mn}(\mathrm{III})(\mathrm{L1})(\mathrm{OAc})_{2}\right]\left(\mathrm{ClO}_{4}\right)^{b}$ & -4.18 & 1.925 & 2.192 & 0.267 \\
{$\left[\mathrm{Mn}(\mathrm{II}) \mathrm{Mn}(\mathrm{III})(\mathrm{BPTBMP})(\mathrm{OAc})_{2}\right]\left(\mathrm{ClO}_{4}\right)^{42}$} & -5.45 & 1.922 & 2.179 & 0.257 \\
{$\left[\mathrm{Mn}(\mathrm{II}) \mathrm{Mn}(\mathrm{III})(\mathrm{BCMP})(\mathrm{OAc})_{2}\right]\left(\mathrm{ClO}_{4}\right)_{2}{ }^{41}$} & -7.7 & 1.957 & 2.17 & 0.213 \\
{$\left[\mathrm{Mn}(\mathrm{II}) \mathrm{Mn}(\mathrm{III})(\mathrm{BPMP})(\mathrm{OAc})_{2}\right]\left(\mathrm{ClO}_{4}\right)^{41}$} & -6.0 & 1.903 & 2.193 & 0.29 \\
{$\left[\mathrm{Mn}(\mathrm{II}) \mathrm{Mn}(\mathrm{III})(\mathrm{BPPMP})(\mathrm{OAc})_{2}\right]\left(\mathrm{ClO}_{4}\right)_{2}{ }^{40}$} & -4.3 & 1.8727 & 2.2448 & 0.3721 \\
{$\left[\mathrm{Mn}(\mathrm{II}) \mathrm{Mn}(\mathrm{III})(\mathrm{BMIMP})(\mathrm{OAc})_{2}\right]\left(\mathrm{ClO}_{4}\right)_{2}$} & -4.5 & 1.887 & 2.258 & 0.371 \\
{$\left[\mathrm{Mn}(\mathrm{II}) \mathrm{Mn}(\mathrm{III})(\mathrm{BPEMP})(\mathrm{OAc})_{2}\right]\left(\mathrm{ClO}_{4}\right)_{2}$} & -4.1 & 1.923 & 2.237 & 0.314 \\
{$\left[\mathrm{Mn}(\mathrm{II}) \mathrm{Mn}(\mathrm{III})(\mathrm{BPAMP})\left(\mathrm{OOC}_{6} \mathrm{H}_{5}\right)_{2}\right]\left(\mathrm{ClO}_{4}\right)_{2}{ }^{119}$} & -6.3 & 1.905 & 2.184 & 0.279
\end{tabular}

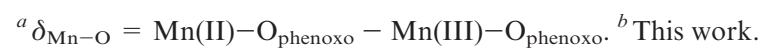

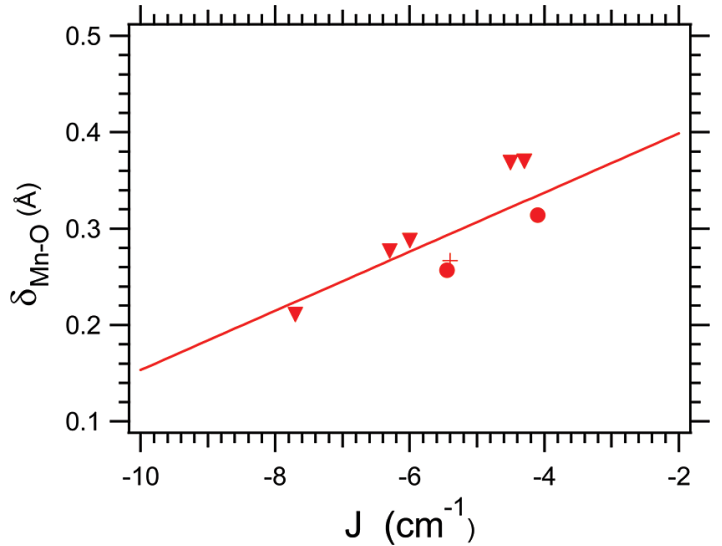

Figure 7. Magneto-structural correlation proposed by Dubois et al. ${ }^{40}$ Data originally included are shown as triangles, subsequent data as circles, and the current complex as a cross. The straight line shows the linear best fit to the data.

Table 2 shows the exchange coupling and key bond lengths reported for ( $\mu$-phenoxo)bis( $\mu$-carboxylato) $\mathrm{Mn}(\mathrm{II}) \mathrm{Mn}(\mathrm{III})$ dimers. Dubois et al ${ }^{40}$ have identified a magneto-structural relationship for this type of dimer based on the parameter $\delta_{\mathrm{Mn}-\mathrm{O}}$ (difference between $\mathrm{Mn}$ (III) $-\mathrm{O}_{\text {phenoxo }}$ and $\mathrm{Mn}(\mathrm{II})-\mathrm{O}_{\text {phenoxo }}$ distances). The correlation is shown in Figure 7, where the observed values for $J$ are plotted as a function of $\delta_{\mathrm{Mn}-\mathrm{O}}$. The increase in the magnitude of $J$, observed for a decrease in $\delta_{\mathrm{Mn}-\mathrm{O}}$, can be understood in terms of both the decrease in the $\mathrm{Mn}(\mathrm{II})-\mathrm{O}$ bond length (greater overlap increases exchange coupling) and the increase in $\mathrm{Mn}(\mathrm{III})-\mathrm{O}_{\text {phenoxo }}$ bond length (decrease in the Jahn-Teller distortion). The Jahn-Teller distortion is associated with the Mn(III) center and can be described either as a compression along the $\mathrm{Mn}(\mathrm{III})-\mathrm{O}_{\text {phenoxo }}$ axis or an elongation perpendicular to this axis. In each case, the $\mathrm{Mn}(\mathrm{III})-\mathrm{O}_{\text {phenoxo }}$ is the shortest bond length, and therefore the $\mathrm{d}_{z^{2}}$ orbital pointing toward the bridging phenoxo is the highest energy dorbital. A shorter $\mathrm{Mn}(\mathrm{III})-\mathrm{O}_{\text {phenoxo }}$ distance (larger $\delta_{\mathrm{Mn}-\mathrm{O}}$, Figure 7) renders the orbital higher in energy and thus less populated, resulting in a smaller exchange coupling, while a longer bond has the opposite effect. ${ }^{40} \mathrm{In}$ the current complex, $\delta_{\mathrm{Mn}-\mathrm{O}}$ is $0.267 \AA$ and using the relation determined by Dubois ${ }^{40}$ yields a $J$ of $-6.5 \mathrm{~cm}^{-1}$, slightly larger than the values found from the magnetic susceptibility $\left(J=-5.0 \mathrm{~cm}^{-1}\right)$ and the VTVH MCD experiments $\left(J=-4.7 \mathrm{~cm}^{-1}\right)$.

(55) Huang, P.; Shaikh, N.; Anderlund, M. F.; Styring, S.; Hammarstrom, L. J. Inorg. Biochem. 2006, 100, 1139 .
Table 3. Intrinsic Hyperfine Values $a$ and Anisotropy $\Delta a$ for the $\mathrm{Mn}(\mathrm{II})$ and $\mathrm{Mn}$ (III) Ions Calculated from the Effective Hyperfine Values Obtained from the Simulation $^{a}$

\begin{tabular}{lccc}
\hline metal center & \multicolumn{1}{c}{$a_{x}, a_{y}, a_{z}$} & $a_{\text {iso }}$ & $\Delta a^{b}$ \\
\hline $\operatorname{Mn}(\mathrm{II})$ & $-67,-51,-112$ & -77 & -53 \\
$\mathrm{Mn}(\mathrm{III})$ & $-46,-47,-92$ & -62 & -46 \\
$\quad{ }^{a}$ All values $\times 10^{-4} \mathrm{~cm}^{-1} \cdot{ }^{b}$ Defined as $a_{z}-1 / 2\left(a_{x}-a_{y}\right)$. &
\end{tabular}

The EPR spectrum of the model complex strongly resembles that of other $\mathrm{Mn}(\mathrm{II}) \mathrm{Mn}$ (III) dimers. ${ }^{41,44,54-59}$ Table 1 shows the simulation parameters used for similar complexes, as well as for catalase and for the species obtained from the reaction of photosystem II with NO. In comparison to the enzyme systems, the [Mn(II)$\mathrm{Mn}(\mathrm{III})(\mathrm{L1})(\mathrm{OAc})_{2} \mathrm{ClO}_{4}$ model complex has a larger rhombic distortion. Huang et al. ${ }^{55}$ reported a thorough analysis of the EPR simulation of the effective $S=1 / 2$ state of an antiferromagnetically coupled $\mathrm{Mn}$ (II)Mn(III) dimer system, and related the effective hyperfine values $A$ to the intrinsic hyperfine values $a$. The calculated spinprojection coefficients are $c_{1}=7 / 3$ for $\mathrm{Mn}(\mathrm{II})$ and $c_{2}=$ $-4 / 3$ for $\mathrm{Mn}(\mathrm{III})^{55,60,61}$ for the $S=1 / 2$ ground state, assuming that $|J|>|D|$.

$$
A_{i}=c_{i} a_{i}
$$

Using this relationship, the intrinsic hyperfine values and the hyperfine anisotropy, $\Delta a$, values can be calculated (Table 3). The intrinsic isotropic hyperfine value of manganese(III) agrees reasonably well with that found for $\mathrm{Mn}(\mathrm{III})$ in $\mathrm{TiO}_{2}, a_{\text {iso }}=-73 \times 10^{-4} \mathrm{~cm}^{-1}$. ${ }^{62}$ The small variation may be attributed to the $\mathrm{O}_{6}$ donor set in $\mathrm{TiO}_{2}$, compared to $\mathrm{N}_{2} \mathrm{O}_{4}$ in the present complex. ${ }^{55}$ The hyperfine anisotropy $\Delta a$ for the manganese(III) ion is as expected. Manganese(III) $\left(\mathrm{d}^{4}\right)$ undergoes a Jahn-Teller distortion in which the ${ }^{5} \mathrm{E}$ term reduces to ${ }^{5} \mathrm{~A}_{1}$ or ${ }^{5} \mathrm{~B}_{1}$, with

(56) Diril, H.; Chang, H.-R.; Zhang, X.; Larsen, S. K.; Potenza, J. A.; Pierpont, C. G.; Schugar, H. J.; Isied, S. S.; Hendrickson, D. N. J. Am. Chem. Soc. 1987, 109, 6207.

(57) Lomoth, R.; Huang, P.; Zheng, J.; Sun, L.; Hammarstrom, L.; Akermark, B.; Styring, S. Eur. J. Inorg. Chem. 2002, 2965.

(58) Buchanan, R. M.; Oberhausen, K. J.; Richardson, J. F. Inorg. Chem. 1988, $27,971$.

(59) Magnuson, A.; Liebisch, P.; Hogblom, J.; Anderlund, M. F.; Lomoth, R.; Meyer-Klaucke, W.; Haumann, M.; Dau, H. J. Inorg. Biochem. 2006, 100, 1234 .

(60) Schafer, K.-O. Exchange coupled manganese complexes: Model systems for the active centres of redox proteins investigated with EPR techniques. Doctoral thesis, Technical University Berlin, Berlin, Germany, 2002

(61) Blondin, G.; Girerd, J.-J. Chem. Rev. 1990, 90, 1359.

(62) Gerritsen, H. J.; Sabisky, E. S. Phys. Rev. 1963, 132, 1507. 
the former corresponding to an empty $\mathrm{d}_{z^{2}}$ orbital, and the latter to an empty $\mathrm{d}_{x^{2}-y^{2}}$ orbital. This distortion results in the intrinsic anisotropy of the hyperfine tensors.

A positive value of $\Delta a$ corresponds to a tetragonally elongated ${ }^{5} \mathrm{~B}_{1}$ ground state and a negative value to a tetragonally compressed ${ }^{5} \mathrm{~A}_{1}$ ground state. ${ }^{63-65}$ The intrinsic anisotropy is expected to be $\left|45 \times 10^{-4}\right| \mathrm{cm}^{-1}, 55,66$ which is in good agreement with the value of $-46 \times 10^{-4}$ $\mathrm{cm}^{-1}$ obtained herein. The negative sign of the intrinsic anisotropy indicates that the $\mathrm{Mn}$ (III) ion is in the ${ }^{5} \mathrm{~A}_{1}$ state, ${ }^{63}$ with the $\mathrm{d}_{z^{2}}$ orbital being the highest (unoccupied) d-orbital. ${ }^{63,67}$ This corresponds to a tetragonally compressed distortion which gives rise to a positive value of the ZFS parameter $D .{ }^{63}$

The identification of a positive $D$ and thus a tetragonally compressed geometry is in contrast to the Jahn-Teller elongation proposed by Karsten et al., ${ }^{15}$ but is consistent with the markedly shorter Mn2-O1 and Mn2-O2 bond lengths along our definition of the $z$ axis, indicating that this corresponds to the tetragonally compressed axis and the orientation of the unfilled $\mathrm{d}_{z^{2}}$ orbital. Interestingly, the bulk of manganese(III) complexes studied by EPR have tetragonally elongated geometries and negative values of $D .^{68}$

The isotropic hyperfine matrix of the manganese(II) ion is consistent with that reported for isolated manganese(II) in crystalline hosts. ${ }^{62}$ However, the significant anisotropy of the hyperfine matrix in this center is unexpected. The minor distortion from octahedral geometry is insufficient to cause such a large anisotropy, and so it is attributed to "transferred anisotropy". That is, in weakly exchange coupled dimers where $S_{1}=S_{2}+1 / 2$, the effective hyperfine coupling of each metal ion is influenced by the ZFS term of both metal ions, and the exchange coupling constant. ${ }^{69}$ In this way the anisotropy of the trivalent manganese can be transferred to the divalent ion. ${ }^{55,60}$

Also of note, and similar to that observed in the related complex, ${ }^{55}$ are the rhombic line width parameters, where the $x$ - and $y$-components have much larger linewidths than the $z$-component. While the main contribution to the EPR line width is the transverse relaxation time, this effect would be expected to be homogeneous. ${ }^{55,70}$ Other possible sources of line broadening include anisotropic $\mathrm{T}_{1}$ 's and the anisotropic distributions of local magnetic fields arising from anisotropic ZFS, electronic Zeeman, and hyperfine interactions.

4.1.3. Zero Field Splitting Parameters. The MCD and absorption spectra of the complex are dominated by

(63) Campbell, K. A.; Force, D. A.; Nixon, P. J.; Dole, F.; Diner, B. A.; Britt, R. D. J. Am. Chem. Soc. 2000, 122, 3754

(64) Kripokapic, I.; Noble, C.; Klitgaard, S.; Tregenna-Piggott, P.; Weihe, H.; Barra, A.-L. Angew. Chem., Int. Ed. 2005, 44, 3613.

(65) Boca, R. Coord. Chem. Rev. 2004, 248, 757.

(66) Zheng, M.; Khangulov, S. V.; Dismukes, G. C.; Barynin, V. V. Inorg. Chem. 1994, 33, 382.

(67) Krzystek, J.; Yeagle, G. J.; Park, J.-H.; Britt, R. D.; Meisel, M. W.; Brunel, L.-C.; Telser, J. Inorg. Chem. 2006, 45, 9926.

(68) Krzystek, J.; Ozarowski, A.; Telser, J. Coord. Chem. Rev. 2006, 250, 2308

(69) Sage, J. T.; Xia, Y.-M.; Debrunner, P. G.; Keough, D. T.; de Jersey, J.; Zerner, B. J. Am. Chem. Soc. 1989, 111, 7239.

(70) Weil, J. A.; Bolton, J. R.; Wertz, J. E. Electron paramagnetic resonance: Elementary theory and practical applications; John Wiley \& Sons: New York, 1994. ligand-to-metal charge transfer (LMCT) bands at $\sim 450$ nm. In the MCD spectrum, these bands show usual $C$ term behavior. However, the weak sharp bands at 426 and $472 \mathrm{~nm}$ show unusual temperature dependence, as they do not appear to significantly decrease in intensity as a function of temperature. The low intensity and narrow bandwidth of the absorption peaks indicates that they likely arise from spin flip transitions. ${ }^{46,47,71-73}$ These are ligand field independent transitions in which the excited state has the same orbital but different spin configuration as the ground state. These states appear as horizontal lines in the Tanabe-Sugano diagram (see Supporting Information, Figure S2). ${ }^{47}$ Similar weak, sharp transitions have previously been observed in various manganese(III) and manganese(II) complexes, ${ }^{45-47,49,72,74-76}$ and at these energies, the bands are probably attributable to transitions associated with the $\mathrm{Mn}$ (III) center arising from ligand field components of the ${ }^{3} \mathrm{H}$ term. ${ }^{46}$

There are two main mechanisms by which spin forbidden transitions may gain intensity in a dimer. ${ }^{77-81}$ First, intensity may be gained through a single ion mechanism, which is due to the combined action of the odd-parity ligand field at the single-ion site and spin-orbit coupling. ${ }^{47,78-81}$ This mechanism always contributes to the intensity of the spin forbidden transitions in a dimer since there can be no center of inversion at the single ion site, and may be a significant contributor to intensity in single excitations of weakly coupled systems. The second mechanism is an electric-dipole exchange mechanism, termed the Tanabe mechanism. ${ }^{78-80}$ This is the most effective intensity-providing mechanism for pair transitions within $\mathrm{t}_{2}$ orbitals, ${ }^{78-80}$ and relies heavily on overlap between the magnetic orbitals of the constituent centers. Either of these mechanisms could be responsible for the intensity of the single ion spin forbidden transitions observed.

The VTVH MCD data revealed weak antiferromagnetic coupling with $J=-4.7 \mathrm{~cm}^{-1}$, similar to the solid state value $\left(J=-5.0 \mathrm{~cm}^{-1}\right)$. A tetragonal ZFS parameter associated with the manganese(III) center was found to be $D=4.3 \mathrm{~cm}^{-1}$. Similarly to the fit of the magnetic susceptibility data, the rhombic parameters $E$ could not be determined because of the over parametrization of the model. While the fit is again relatively insensitive to the value of $D$, the similar values obtained from both the magnetic susceptibility and the VTVH MCD lends some confidence to this value. Other reported values for the single ion $\mathrm{Mn}$ (III) $D$ parameter derived from a coupled system have been in the range $|D| \sim 1-2 \mathrm{~cm}^{-1}, 47,49$ and

(71) Gamelin, D. R.; Kirk, M. L.; Stemmler, T. L.; Pal, S.; Armstrong, W. H.; Penner-Hahn, J. E.; Solomon, E. I. J. Am. Chem. Soc. 1994, 116, 2392. (72) Mathoniere, C.; Kahn, O. Inorg. Chem. 1994, 33, 2103.

(73) Gerloch, M.; Constable, E. C. The Intensities of d-d spectra. In Transition Metal Chemistry; VCH: Weinheim, 1994.

(74) Kohler, P.; Massa, W.; Reinen, D.; Hofmann, B.; Hoppe, R. Z. Anorg. Allg. Chem. 1978, 446, 131.

(75) Brunold, T. C.; Gamelin, D. R.; Solomon, E. I. J. Am. Chem. Soc. 2000, 122,8511 .

(76) Ferguson, J.; Guggenheim, H. J.; Tanabe, Y. J. Phys. Soc. Jpn. 1966, 21,692 .

(77) Fujiwara, T.; Gebhardt, W.; Petanides, K.; Tanabe, Y. J. Phys. Soc. Jpn. 1972, 33, 39 .

(78) Schenker, R.; Weihe, H.; Güdel, H. Inorg. Chem. 2001, 40, 4319.

(79) Güdel, H. Comments Inorg. Chem. 1984, 3, 189.

(80) Schenker, R.; Weihe, H.; Güdel, H. Inorg. Chem. 1999, 38, 5593

(81) Decurtins, S.; Güdel, H. Inorg. Chem. 1982, 21, 3598. 


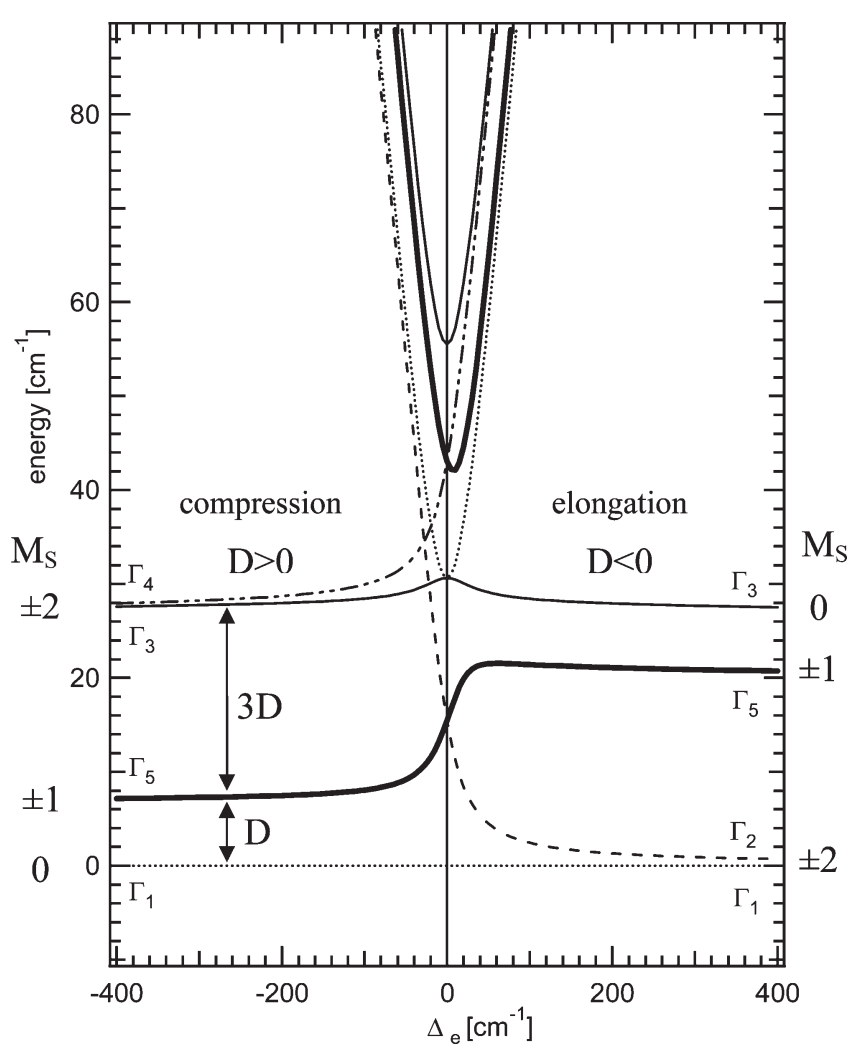

Figure 8. Ground state multiplet of a $\mathrm{d}^{4}$ system as a function of the spitting of the $\mathrm{e}_{\mathrm{g}}$ orbitals $\Delta_{\mathrm{e}}=E\left(\mathrm{~d}_{x^{2}-y^{2}}\right)-E\left(\mathrm{~d}_{z^{2}}\right)$. Full d ${ }^{4}(210 \times 210)$ basis with $\xi=284 \mathrm{~cm}^{-1}, B=912 \mathrm{~cm}^{-1}, C=2940 \mathrm{~cm}^{-1}$ set at $80 \%$ of their free-ion values. Octahedral splitting $\Delta=10,000 \mathrm{~cm}^{-1}, \Delta_{\mathrm{t} 2}=1 / 4 \Delta_{\mathrm{e}}$.

led us to initially question our fitted value. However, ligand field calculations for $\mathrm{Mn}(\mathrm{III})$ shown in Figure 8 as a function of the tetragonal ligand field, support a larger $D$. Here, an octahedral splitting of $10,000 \mathrm{~cm}^{-1}$ is used and the tetragonal field quantified by the difference in the energy of the $\mathrm{e}_{\mathrm{g}}$ d-orbitals: $\Delta_{\mathrm{e}}=E\left(\mathrm{~d}_{x^{2}-y^{2}}\right)-E\left(\mathrm{~d}_{z^{2}}\right)$. The spin-orbit split ground state multiplet, away from $O_{h}$ $\left(\Delta_{\mathrm{e}}=0\right)$ symmetry, consists of the five energy levels labeled by their irreducible representations $\left(\Gamma_{\mathrm{i}}\right)$ of the $D_{4 h}$ double group $\left(\Gamma_{5}\right.$ is doubly degenerate). These are the five levels that an $S=2$ spin Hamiltonian approximates. The ZFS parameter $D$ can be associated with the energy difference between the lowest $\left(\Gamma_{1}\right)$ level and the first pair $\left(\Gamma_{5}\right)$ for $\Delta_{\mathrm{e}}<0$, or the difference between the $\Gamma_{5}$ pair and the $\Gamma_{3}$ level $\Delta_{\mathrm{e}}>0$. Moreover, it is seen that these levels and their splitting are independent of the degree of the tetragonal distortion.

The magnitude of $D$ has often been rationalized by the simple formulas given by Abragam and Bleaney ${ }^{43}$ based on the perturbations within the $\left({ }^{5} \mathrm{E}_{\mathrm{g}},{ }^{5} \mathrm{~T}_{2 \mathrm{~g}}\right)$ multiplets. In fact these formulas are rather poor approximations, predicting a $D$ value of $\sim 2 \mathrm{~cm}^{-1}$, about half the value obtained from the data shown in Figure 8. We have investigated this further (Supporting Information, Figure S2) and find similar values to the perturbation expressions if only the quintets are included in the calculation. To reproduce the values of the full ligand field calculation, one must also include the triplet with the quintet states.

The spin-orbit coupling between the quintet ground state and the triplet excited states are therefore important in determining the ZFS of the ground state. This is also

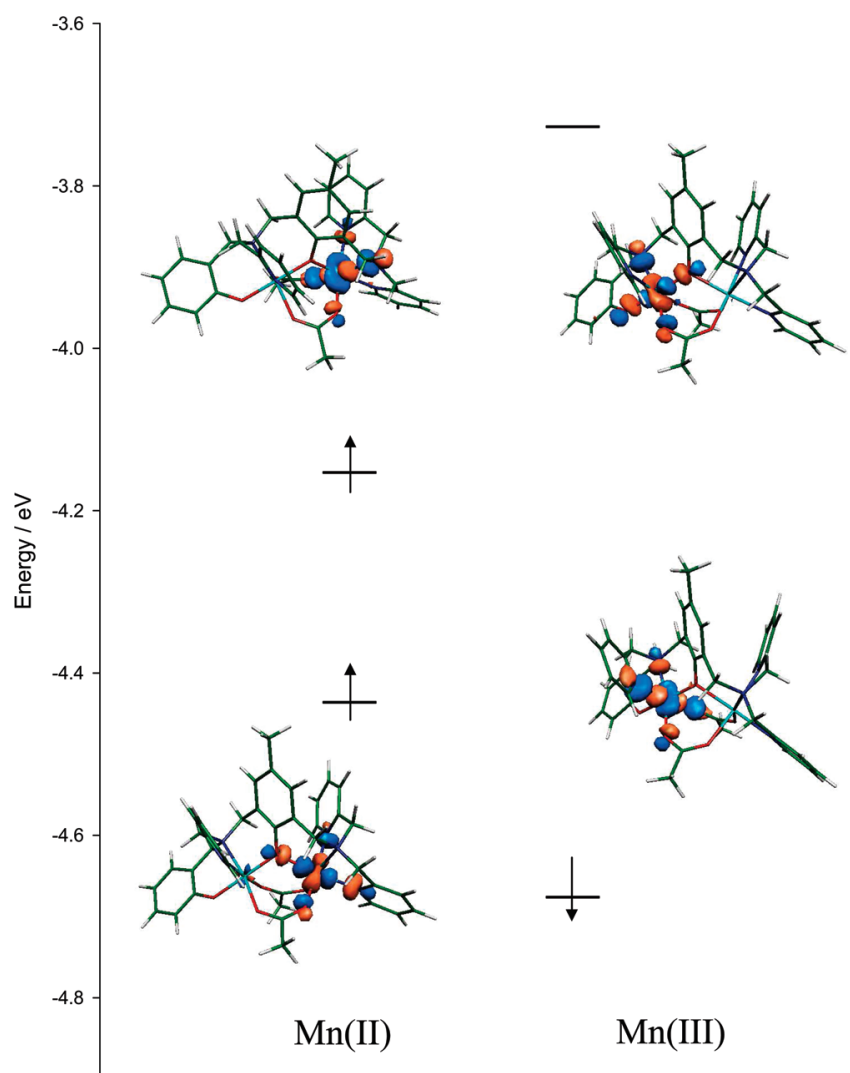

Figure 9. Calculated orbitals of $\left[\mathrm{Mn}(\mathrm{II}) \mathrm{Mn}(\mathrm{III})(\mathbf{L 1})(\mathrm{OAc})_{2}\right]^{+}$showing the contribution of the metal based $\left(x^{2}-y^{2}, z^{2}\right) \mathrm{d}$-orbitals on the $\mathrm{Mn}$ (II) (left) and $\mathrm{Mn}(\mathrm{III})$ (right) centers.

consistent with the sharp features observed in the spectrum being assigned to the spin-forbidden transitions to states associated with $\mathrm{Mn}(\mathrm{III})$ triplet states. It should be noted that the sign of the ZFS parameter $D$ is essentially ambiguous in the pure rhombic limit when $|E / D|=1 / 3$. In this case identical levels are obtained for $D$ defined positive (indicating a predominant compression) or negative (indicating an elongation in a perpendicular direction). The most certain values of $D$ are obtained from single ion studies where high field EPR studies were employed to determine $D=-4.52 \mathrm{~cm}^{-1}$ for an elongated, ${ }^{82}$ and $D=3.53$ $\mathrm{cm}^{-1}$ for compressed ${ }^{83} \mathrm{Mn}$ (III) complexes, consistent with the magnitude of the value obtained here.

4.1.4. Electronic Structure Calculations. Figure 9 shows the calculated energy levels obtained from DFT for the highest occupied and lowest unoccupied orbitals of $e_{\mathrm{g}}$ like character centered on Mn(II) (Figure 9, left) and $\mathrm{Mn}$ (III) (right). The calculated electronic structure agrees well with many of the conclusions reached experimentally. The metal parts of the orbitals have mixed $\mathrm{d}_{z^{2}} / \mathrm{d}_{x^{2}-y^{2}}$ character and are antibonding with respect to the ligand part of the orbitals. The lowest unoccupied Mn(III) based orbital approximates a $\mathrm{d}_{z^{2}}$ orbital oriented along the $\mathrm{Mn}(\mathrm{III})-\mathrm{O} 1$ direction, indicating an effective ligand field compression along this axis. The splitting of the $\mathrm{Mn}(\mathrm{III})$ based $\mathrm{e}_{\mathrm{g}}$ orbital is much larger than the $\mathrm{Mn}(\mathrm{II})$ based

(82) Krzystek, J.; Yeagle, G. J.; Park, J.-H.; Britt, R. D.; Meisel, M. W.; Brunel, L.-C.; Telser, J. Inorg. Chem. 2003, 42, 4610.

(83) Scheifele, Q.; Riplinger, C.; Neese, F.; Weihe, H.; Barra, A.-L.; Juranyi, F.; Podlesnyak, A.; Tregenna-Piggott, P. L. W. Inorg. Chem. 2008, 47,439 . 
orbitals, a measure of the Jahn-Teller driving force of the $\mathrm{d}^{4}$ configuration. That the Jahn-Teller distortion has the opposite sign to that expected for a $\mathrm{d}^{4}$ configuration is due to the effective compression provided by the $\mathrm{O} 1$ and $\mathrm{O} 2$ ligating atoms. ${ }^{84}$ Calculations of the reduced $\mathrm{Mn}(\mathrm{II}) \mathrm{Mn}-$ (II) complex (Supporting Information, Figure S4) show that the $\mathrm{e}_{\mathrm{g}}$ energy separation is greater for the Mn2 site than the Mn1 site because of the effective compression of the $\mathrm{N}_{2} \mathrm{O}_{4}$ coordination sphere. However, the e $e_{\mathrm{g}}$ orbital splitting in the Mn2 site of the Mn(II)Mn(III) complex (Figure 9, right) is about a factor of 2 larger still, indicating that the splitting in this case is principally due to the Jahn-Teller effect, not solely to the ligand environment of the Mn2 site. The overall energy separation of the averages of one electron orbitals of $e_{g}$ and $t_{2 g}$ like character for the $\mathrm{Mn}(\mathrm{II})$ and $\mathrm{Mn}(\mathrm{III})$ sites in the $\mathrm{Mn}(\mathrm{II})$ $\mathrm{Mn}(\mathrm{III})$ complex are 12,900 and $16,900 \mathrm{~cm}^{-1}$, respectively. This illustrates the larger effective octahedral ligand field about the Mn(III) ion, as expected.

Finally, calculations have been made on the ferromagnetic high-spin states to be able to calculate the coupling constants using standard methodology. ${ }^{85}$ The calculations indicate that the broken-symmetry states are more stable than the spin aligned states, and thus antiferromagnetic coupling is predicted, in agreement with experiment. However, the calculated $J$ values are larger in magnitude than those observed experimentally, $J=$ $-24 \mathrm{~cm}^{-1}$ for $[\mathrm{Mn}(\mathrm{III}) \mathrm{Mn}(\mathrm{II})]$ and $-15 \mathrm{~cm}^{-1}$ for [Mn(II)Mn(II)]. Plots of orbitals that show coupling between the two Mn sites have been made (Supporting Information, Figure S5) for cases where the interactions are through the bridging phenolate or the acetate orbitals.

4.2. Catalytic Properties and Mechanism of Action. In addition to the catalase activity previously reported for the manganese dimer, ${ }^{15}$ the complex also acts as a hydrolase. The activity observed is lower than that of the isostructural complexes with $\mathrm{Fe}(\mathrm{III}) \mathrm{M}(\mathrm{II})$ centers $\left(k_{\mathrm{cat}}=\right.$ $3 \times 10^{-3} \mathrm{~s}^{-1}, 4.5 \times 10^{-4} \mathrm{~s}^{-1}, 7.3 \times 10^{-4} \mathrm{~s}^{-1}$, and $1.8 \times$ $10^{-3} \mathrm{~s}^{-1}$ for systems with $\mathrm{M}=\mathrm{Fe}, \mathrm{Mn}, \mathrm{Zn}$, or $\mathrm{Cu}$, respectively), ${ }^{18,22}$ and has a $k_{\text {cat }}=5.4( \pm 0.6) \times 10^{-4} \mathrm{~s}^{-1}$. However, the complex binds the substrate, BDNPP, more tightly than most other isostructural complexes, with a $K_{\mathrm{M}}=3.2 \pm 0.8 \mathrm{mM}$, which is similar to that observed $(2.1 \mathrm{mM})$ for the isostructural $\mathrm{Fe}(\mathrm{III}) \mathrm{Mn}$ (II) complex. ${ }^{86}$

Interestingly, the complex displays a catalytic behavior very different to that of the $\left[\mathrm{Fe}(\mathrm{III}) \mathrm{M}(\mathrm{II})(\mathbf{L 1})(\mathrm{OAc})_{2}\right]^{+}$ complexes (where $\mathrm{M}=\mathrm{Cu}, \mathrm{Zn}, \mathrm{Mn}, \mathrm{Fe}, \mathrm{Ni}$ ). ${ }^{86-91}$ Instead

(84) Tregenna-Piggott, P. L. W. Inorg. Chem. 2008, 47, 448.

(85) Delfs, C. D.; Stranger, R. Inorg. Chem. 2001, 40, 3061.

(86) Karsten, P.; Neves, A.; Bortoluzzi, A. J.; Lanznaster, M.; Drago, V. Inorg. Chem. 2002, 41, 4624.

(87) Batista, S. C.; Neves, A.; Bortoluzzi, A. J.; Vencato, I.; Peralta, R. A.; Szpoganicz, B.; Aires, V. V. E.; Terenzi, H.; Severino, P. C. Inorg. Chem. Commun. 2003, 6, 1161

(88) Lanznaster, M.; Neves, A.; Bortoluzzi, A. J.; Szpoganicz, B.; Schwingel, E. Inorg. Chem. 2002, 41, 5641.

(89) Lanznaster, M.; Neves, A.; Bortoluzzi, A. J.; Aires, V. V. E.; Szpoganicz, B.; Terenzi, H.; Severino, P. C.; Fuller, J. M.; Drew, S. C.; Gahan, L. R.; Hanson, G. R.; Riley, M. J.; Schenk, G. J. Biol. Inorg. Chem. 2005, 10, 319 .

(90) Schenk, G.; Peralta, R. A.; Batista, S. C.; Bortoluzzi, A. J.; Szpoganicz, B.; Dick, A. K.; Herrald, P.; Hanson, G. R.; Szilagyi, R. K.; Riley, M. J.; Gahan, L. R.; Neves, A. J. Biol. Inorg. Chem. 2008, 13, 139.

(91) Smith, S. J.; Casellato, A.; Hadler, K. S.; Mitić, N.; Riley, M. J.; Bortoluzzi, A. J.; Szpoganicz, B.; Schenk, G.; Neves, A.; Gahan, L. R. J. Biol. Inorg. Chem. 2007, 12, 1207. of a bell-shaped $\mathrm{pH}$ dependence, a monoprotic behavior is noted, resembling the $\mathrm{pH}$-activity profiles observed in some dizinc and dicadmium complexes, ${ }^{92,93}$ and in phosphodi- and triesterases such as the glycerophosphodiestease from Enterobacter aerogenes (GpdQ) $)^{92,94}$ and the organophosphate hydrolase from Pseudomonas diminuta (PTE) ${ }^{95}$ The complex was not stable under the conditions of potentiometric titration, preventing the determination of other, catalytically silent, $\mathrm{p} K_{\mathrm{a}}$ values.

The $\mathrm{p} K_{\mathrm{a}}$ of hexaaqua manganese(III) is $\sim 1,{ }^{96}$ precluding the assignment of the catalytically relevant $\mathrm{p} K_{\mathrm{a}}$ of 8.2 to the formation of a $\mathrm{Mn}(\mathrm{III})-\mathrm{OH}$ species. Instead, comparison to $\left[\mathrm{Fe}(\mathrm{III}) \mathrm{Mn}(\mathrm{II})(\mathbf{L 1})(\mathrm{OAc})_{2}\right]^{+86}$ and other $\mathrm{Mn}(\mathrm{II})$ complexes ( $K_{\mathrm{a}}$ 's $\left.8.3-9.5\right)^{97-99}$ supports the assignment of this $\mathrm{p} K_{\mathrm{a}}$ to a $\mathrm{Mn}(\mathrm{II})$ bound water. In binuclear manganese(II) enzymes, such as $\lambda$ protein phosphatase, PTE and arginase, bridging hydroxide moieties function as nucleophiles and have $\mathrm{p} K_{\mathrm{a}}$ values in the range of 7-8.5.,100-104 In contrast, hexaaqua manganese(II) has a $\mathrm{p} K_{\mathrm{a}}$ of $\sim 10.5,{ }^{96}$ and while the $\mathrm{p} K_{\mathrm{a}}$ of terminally $\mathrm{Mn}$ (II)-bound water has been reported to be as low as $9.2,{ }^{99}$ the value of 8.2 obtained here is indicative of a bridging water molecule between two $\mathrm{Mn}$ (II) ions. However, this would suggest that the $\mathrm{Mn}$ (III) ion is reduced to $\mathrm{Mn}$ (II) (which would account for a $\mathrm{Mn}$ (II) $-\mathrm{OH}-\mathrm{Mn}$ (II) nucleophile, as observed under the conditions of mass spectrometry). Reduction of the trivalent ion is, however, not likely, as no significant changes to the absorption spectrum (which is primarily due to the trivalent metal ion) were observed in the complex under catalytic conditions as would be expected if the chromophoric trivalent manganese was reduced. ${ }^{42}$ Thus, we tentatively assign the catalytically relevant $\mathrm{p} K_{\mathrm{a}}$ to the deprotonation of a water molecule bound terminally to the divalent manganese, and which is involved in a hydrogen bonding interaction with a hydroxide coordinated to the trivalent metal ion. This hydrogen bonding interaction is expected to decrease the $\mathrm{p} K_{\mathrm{a}}$ of the $\mathrm{Mn}(\mathrm{II})-$ bound water. ${ }^{105-107}$ Indeed, in carbonic anhydrase,

(92) Mirams, R. E.; Smith, S. J.; Hadler, K. S.; Ollis, D. L.; Schenk, G.; Gahan, L. R. J. Biol. Inorg. Chem. 2008, 13, 1065.

(93) Bazzicalupi, C.; Bencini, A.; Berni, E.; Bianchi, A.; Fedi, V.; Fusi, V.; Giorgi, C.; Paolettti, P.; Valtancoli, B. Inorg. Chem. 1999, 38, 4115.

(94) Hadler, K. S.; Tanifum, E. A.; Yip, S. H.-C.; Mitic, N.; Guddat, L. W.; Jackson, C. J.; Gahan, L. R.; Nguyen, K.; Carr, P. D.; Ollis, D. L.; Hengge, A. C.; Larrabee, J. A.; Schenk, G. J. Am. Chem. Soc. 2008, 130, 14129 .

(95) Aubert, S. D.; Li, Y.; Raushel, F. M. Biochemistry 2004, 43, 5707.

(96) Burgess, J. Metal Ions in Solution; Ellis Horwood: Chichester, 1978.

(97) Yashiro, M.; Higuchi, M.; Komiyama, M.; Ishii, Y. Bull. Chem. Soc. Jpn. 2003, 76, 1813.

(98) Bigbee, W. L.; Dahlquist, F. W. Biochemistry 1977, 16, 3798

(99) Li, J.-Z.; Li, H.-B.; Feng, F.-M.; Xie, J.-Q.; Li, S.-X.; Zhou, B.; Qin, S.-Y. Chin. J. Chem. 2005, 23, 678 .

(100) Kuhn, N. J.; Ward, S.; Piponski, M.; Young, T. W. Arch. Biochem. Biophys. 1995, 320, 24.

(101) Kuhn, N. J.; Talbot, J.; Ward, S. Arch. Biochem. Biophys. 1991, 286, 217.

(102) Badarau, A.; Page, M. I. Biochemistry 2006, 45, 10654

(103) Hoff, R. H.; Mertz, P.; Rusnak, F.; Hengge, A. C. J. Am. Chem. Soc. 1999, 121, 6382 .

(104) Samples, C. R.; Howard, T.; Raushel, F. M.; DeRose, V. J. Biochemistry 2005, 44, 11005.

(105) Krebs, J. F.; Ippolito, J. A.; Christianson, D. W.; Fierke, C. A. J. Biol. Chem. 1993, 268, 27459.

(106) Horton, N. C.; Newberry, K. J.; Perona, J. J. Proc. Natl. Acad. Sci. U.S.A. 1998, 95, 13489.

(107) Bauer-Siebenlist, B.; Meyer, F.; Farkas, E.; Vidovic, D.; Dechert, S. Chem. Eur. J. 2005, 11, 4349. 
hydrogen bonding interactions decrease the $\mathrm{p} K_{\mathrm{a}}$ of a terminally zinc bound water by up to $2.5 \mathrm{pH}$ units. ${ }^{105}$ The presence of water and hydroxide ligands are supported by the mass spectrometry conducted under kinetic solvent conditions, and similar hydrogen bonding interactions are proposed in metallohydrolases such as leucine aminopeptidase, ${ }^{108} \beta$-lactamases, ${ }^{109} \mathrm{GdpQ},{ }^{94}$ and have been studied in binuclear zinc ${ }^{107,110,111}$ and nickel ${ }^{112}$ complexes.

The observation of residual activity at low $\mathrm{pH}$ and the presence of only one catalytically relevant $\mathrm{p} K_{\mathrm{a}}$ indicates that the reaction mechanism employed by the $\mathrm{Mn}(\mathrm{II}) \mathrm{Mn}-$ (III) complex is different from that of isostructural complexes of the M(II)Fe(III) type. On the basis of mechanistic schemes discussed for other isostructural complexes ${ }^{15,22,86,90,91,113,114}$ and several enzymatic systems (e.g., PAPs ${ }^{18,19}$ ) the following reaction mechanism for the $\mathrm{Mn}(\mathrm{II}) \mathrm{Mn}(\mathrm{III})$ complex is proposed. At low $\mathrm{pH}$ $(<8)$ the likely nucleophile involved in hydrolysis is a terminally Mn(III) bound hydroxide (Scheme 2), with the substrate bound only to the divalent metal ion. In this respect, the mechanism is similar to that proposed for the M(II)Fe(III) complexes. ${ }^{86,90,114}$ According to the mass spectrometric data (see above) and in agreement with similar data for related model systems, a terminal coordination on the $\mathrm{Mn}(\mathrm{II})$ position is occupied by $\mathrm{H}_{2} \mathrm{O}$ in the absence of substrate. ${ }^{115}$ As discussed above, this water is assigned a $\mathrm{p} K_{\mathrm{a}}$ of 8.2. Since the deprotonation of this ligand would slow down ligand exchange a reduction in catalytic rate because of slow substrate binding would be expected. However, the opposite effect is observed (Figure 2). Thus, we propose that upon deprotonation the terminal water ligand becomes bridging, thus vacating a coordination site for the substrate on the $\mathrm{Mn}(\mathrm{II})$ center (Scheme 2). A similar rearrangement has been proposed for the isostructural $\mathrm{Ni}(\mathrm{II}) \mathrm{Fe}(\mathrm{III})$ system. ${ }^{90}$ The formation of a $\mu-\mathrm{OH}$ bridge at higher $\mathrm{pH}$ would be expected to increase the magnitude of the exchange coupling. Unfortunately, it is at present not possible to acquire MCD and EPR data of sufficient quality at high $\mathrm{pH}$ since the addition of an aqueous buffer to the solvent solution leads to a drastic reduction in data quality.

In essence, both the bridging and the terminally Mn(III)-bound hydroxide can act as nucleophiles to initiate hydrolysis and at present the two possibilities cannot be distinguished unambiguously (it is of interest to note that in PAPs it was observed that both the bridging and the

(108) Erhardt, S.; Jaime, E.; Weston, J. J. Am. Chem. Soc. 2005, 127, 3654. (109) Suarez, D.; Brothers, W. N.; Merz, K. M. Biochemistry 2002, 41 6615

(110) Bauer-Siebenlist, B; Meyer, F; Farkas, E.; Vidovic, D.; CuestaSeijo, J. A.; Herbst-Irmer, R.; Pritzkow, H. Inorg. Chem. 2004, 43, 4189.

(111) Meyer, F.; Rutsch, P. Chem. Commun. 1998, 1037.

(112) Buchler, S.; Meyer, F.; Kaifer, E.; Pritzkow, H. Inorg. Chim. Acta 2002, 337, 371 .

(113) Neves, A.; de Brito, M. A.; Vencato, I.; Drago, V.; Griesar, K.; Haase, W. Inorg. Chem. 1996, 35, 2360.

(114) Neves, A.; Lanznaster, M.; Bortoluzzi, A. J.; Peralta, R. A.; Casellato, A.; Castellano, E. E.; Herrald, P.; Riley, M. J.; Schenk, G. J. Am. Chem. Soc. 2007, 129, 7486.

(115) Xavier, F. R.; Neves, A.; Casellato, A.; Peralta, R. A.; Bortoluzzi, A. J.; Szpoganicz, B.; Severino, P. C.; Terenzi, H.; Tomkowicz, Z.; Ostrovsky, S.; Haase, W.; Ozarowski, A.; Krzystek, J.; Telser, J.; Schenk, G.; Gahan, L. R. Inorg. Chem. 2009, 48, 7905.
Scheme 2. Reaction Mechanism for Hydrolysis of BDNPP by $\left[\mathrm{Mn}(\mathrm{II}) \mathrm{Mn}(\mathrm{III})(\mathbf{L 1})(\mathrm{OAc})_{2}\right] \mathrm{ClO}_{4}$ at High and Low $\mathrm{pH}$

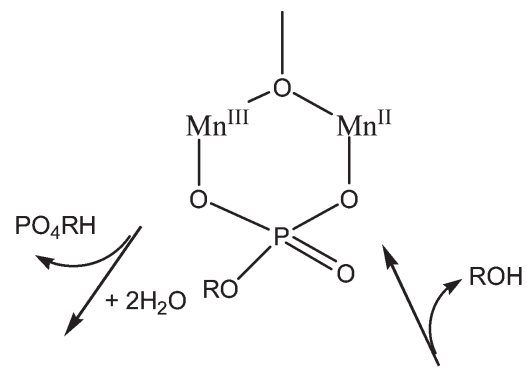<smiles>[M]O[Al]1O[Al]O[Al]1C</smiles>

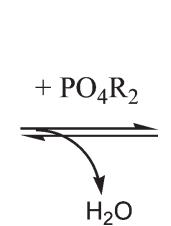<smiles>C=[PH+]C</smiles>

LOW pH

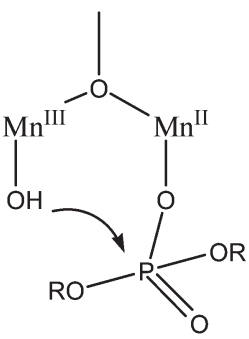<smiles></smiles>
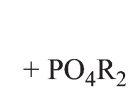<smiles>[M]C1CCCCC1OC</smiles><smiles>O</smiles>

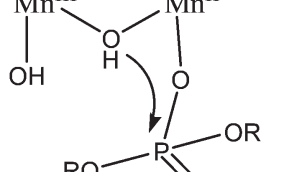<smiles>CC1C(C)[C@@H](C)C1[Po](=O)[O-]</smiles>

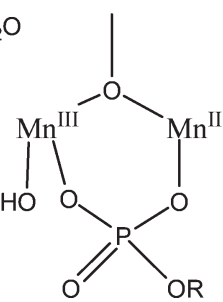<smiles>C1CCC(C2CCCCC2)CC1</smiles><smiles>[R6]P1(=O)CCCCC1</smiles>

$\mathrm{ROH}$

terminal hydroxide can act as a nucleophile depending on the substrate used in the reaction). ${ }^{19}$ Since a Mn(III)bound hydroxide would be expected to be as reactive as a $\mathrm{Fe}$ (III)-bound one, the observed lower activity of the $\mathrm{Mn}(\mathrm{II}) \mathrm{Mn}$ (III) complex suggests the bridging hydroxide as the nucleophile (because of its poorer nucleophilicity $\left.{ }^{14,116,117}\right)$. It is interesting to note that the decreased activity of this $\mathrm{Mn}$ (II)Mn(III) model in comparison to its binuclear $\mathrm{M}(\mathrm{II}) \mathrm{Fe}(\mathrm{III})$ counterparts $(\mathrm{M}=\mathrm{Fe}, \mathrm{Zn}, \mathrm{Mn}, \mathrm{Ni}, \mathrm{Cu})$ may reflect the selection of metal ions for specific functions in a biological environment. While manganese is ideal for performing redox type chemistry $^{12}$ in catalases and peroxidases it is rarely used in hydrolytic reactions. ${ }^{2}$

(116) Greatti, A.; Scarpellini, M.; Peralta, R. A.; Casellato, A.; Bortoluzzi, A. J.; Xavier, F. R.; Jovito, R.; de Brito, M. A.; Szpoganicz, B.; Tomkowicz, Z.; Rams, M.; Haase, W.; Neves, A. Inorg. Chem. 2008, 47, 1107.

(117) Klabunde, T.; Sträter, N.; Frohlich, R.; Witzel, H.; Krebs, B. J. Mol. Biol. 1996, 259, 737.

(118) Sarrou, J.; Ioannidis, N.; Deligiannakis, Y.; Petrouleas, V. Biochemistry 1998, 37, 3581

(119) Suzuki, M.; Mikuriya, M.; Murata, S.; Uehara, A.; Oshio, H.; Kida, S.; Saito, K. Bull. Chem. Soc. Jpn. 1987, 60, 4305. 


\section{Summary}

The binuclear manganese model complex with the $\mathbf{L 1}^{\mathbf{2}}$ ligand has been spectroscopically characterized. The complex is weakly antiferromagnetically coupled, typical of phenoxo bridged manganese complexes. The magnetic and electronic properties of the complex have been related to the structure. The EPR and MCD analyses enables the identification of the Jahn-Teller distortion of the Mn(III) center as predominantly a tetragonal compression from the sign of the ZFS and the hyperfine anisotropy. Ligand field and density functional theory have been used to relate the observed zero-field splitting and exchange coupling, respectively, to the compressed geometry. The orientation of the compression is directed along the $\mathrm{Mn}(\mathrm{III})-\mathrm{O}_{\text {phenolate }}$ direction. While this tetragonally compressed geometry is atypical of manganese(III) centers, it has been confirmed here from both the crystal structure and the electronic structure calculations. The unoccupied " $\mathrm{d}_{z}$ " type orbital is directed toward the bridging oxygen and plays a crucial role in the size of the exchange coupling. Empirically, as the $\mathrm{Mn}(\mathrm{III})-\mathrm{O}_{\text {phenolate }}$ is lengthened, and the ligand environment is less compressed the " $\mathrm{d}_{z}$ " type orbital drops in energy and the exchange coupling increases.
In addition to its catalase activity, the complex also operates as a functional phosphodiesterase mimic. In agreement with this system's bifunctionality, we were able to demonstrate mechanistic flexibility here (Scheme 2). As the $\mathrm{pH}$ changes so does the mechanism of action. Thus, the range of functionality of complexes generated with the ligand $\mathbf{L 1}^{2-}$ may reflect, at least in part, how Nature has acquired the ability to tune chemical reactions by using different metal ions in a similar chemical environment.

Acknowledgment. Prof. Keith Murray is thanked for providing the magnetic susceptibility data. The authors acknowledge financial support from the Australian Research Council and access to the Australian National University supercomputer facilities of the National Computational Infrastructure.

Supporting Information Available: Tables of crystallographic data, theoretically calculated structures and Mulliken population analysis, together with figures of mass spectra, ligand field calculation, broken symmetry energy levels and molecular orbitals ( 9 pages). This material is available free of charge via the Internet at http://pubs.acs.org. 